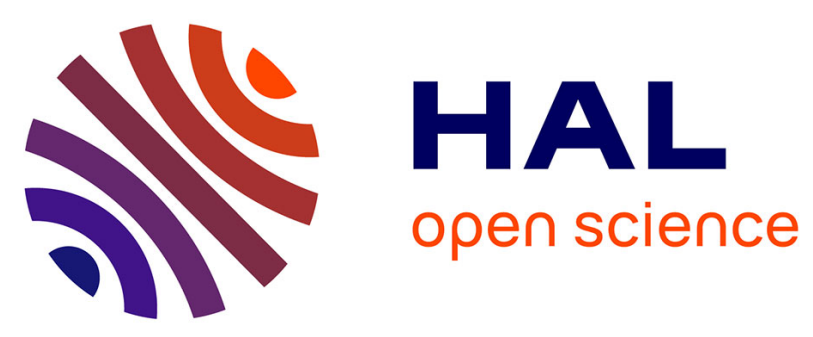

\title{
Timing, cause and impact of the late Eocene stepwise sea retreat from the Tarim Basin (west China)
}

Roderic Bosboom, Guillaume Dupont-Nivet, Arjen Grothe, Henk Brinkhuis, Giuliana Villa, Oleg Mandic, Marius Stoica, Tania Kouwenhoven, Wentao Huang, Wei Yang, et al.

\section{To cite this version:}

Roderic Bosboom, Guillaume Dupont-Nivet, Arjen Grothe, Henk Brinkhuis, Giuliana Villa, et al.. Timing, cause and impact of the late Eocene stepwise sea retreat from the Tarim Basin (west China). Palaeogeography, Palaeoclimatology, Palaeoecology, 2014, 403, pp.101-118. 10.1016/j.palaeo.2014.03.035 . insu-00985321

\section{HAL Id: insu-00985321 https://hal-insu.archives-ouvertes.fr/insu-00985321}

Submitted on 29 Apr 2014

HAL is a multi-disciplinary open access archive for the deposit and dissemination of scientific research documents, whether they are published or not. The documents may come from teaching and research institutions in France or abroad, or from public or private research centers.
L'archive ouverte pluridisciplinaire HAL, est destinée au dépôt et à la diffusion de documents scientifiques de niveau recherche, publiés ou non, émanant des établissements d'enseignement et de recherche français ou étrangers, des laboratoires publics ou privés. 


\title{
Timing, cause and impact of the late Eocene stepwise sea retreat from the Tarim Basin (west China)
}

\author{
Roderic Bosboom* ${ }^{\text {a }}$, Guillaume Dupont-Nivet ${ }^{\mathrm{a}, \mathrm{b}, \mathrm{c}}$, Arjen Grothe ${ }^{\mathrm{d}}$, Henk
}

Brinkhuis $^{\mathrm{d}}$, Giuliana Villa ${ }^{\mathrm{e}}$, Oleg Mandic ${ }^{\mathrm{f}}$, Marius Stoica ${ }^{\mathrm{g}}$, Tanja Kouwenhoven ${ }^{\mathrm{d}}$

Wentao Huang ${ }^{\mathrm{a}, \mathrm{b}, \mathrm{c}}$, Wei Yang ${ }^{\mathrm{b}, \mathrm{c}}$ and ZhaoJie Guo

a Paleomagnetic Laboratory Fort Hoofddijk, Faculty of Geosciences, Utrecht University, Budapestlaan 17, 3584 CD Utrecht, The Netherlands

${ }^{b}$ Key Laboratory of Orogenic Belts and Crustal Evolution, Ministry of Education (Peking University), Beijing 100871, China

c Géosciences Rennes, UMR 6118, Université de Rennes1, Campus de Beaulieu, 35042 Rennes Cedex, France

d Marine Palynology and Palaeoceanography, Laboratory of Palaeobotany and Palynology, Department of Earth Sciences, Faculty of Geosciences, Utrecht University, Budapestlaan 4, 3584 CD Utrecht, The Netherlands

e Dipartimento di Fisica e Scienze della Terra, University of Parma, Viale Usberti, 157A, 43100 Parma, Italy

f Geological-Palaeontological Department, Natural History Museum Vienna, Burgring 7, A-1010 Wien, Austria

g Department of Geology and Paleontology, Faculty of Geology and Geophysics, Bucharest University, Bălcescu Bd. 1, 010041, Romania

*Corresponding author: R.E.Bosboom@uu.nl; +31 (0)30 253- 5246.

\begin{abstract}
A vast shallow epicontinental sea extended across Eurasia and was well-connected to the Western Tethys before it retreated westward and isolated as the Paratethys Sea. However, the palaeogeography
\end{abstract}


and the timing of this westward retreat are too poorly constrained to determine potential wider environmental impacts, let alone understanding underlying mechanisms of the retreat such as global eustacy and tectonism associated to the Indo-Asia collision. Here, an improved chronostratigraphic and palaeogeographic framework is provided for the onset of the proto-Paratethys Sea retreat at its easternmost extent in the Tarim Basin in western China is provided. Five different third-order sealevel cycles can be recognized from the Cretaceous-Paleogene sedimentary record in the Tarim Basin, of which the last two stepped successively westwards as the sea retreated after the maximum third incursion. New biostratigraphic data from the fourth and fifth incursions at the westernmost margin of the Tarim Basin are compared to our recent integrated bio-magneto-stratigraphic results on the fourth incursion near the palaeodepocenter in the south-western part of the basin. While the fourth incursion extended throughout the basin and retreated at $\sim 41 \mathrm{Ma}$ (base C18r), the last and fifth incursion is restricted to the westernmost margin and its marine deposits are assigned a latest Bartonian-early Priabonian age from $\sim 38.0$ to $\sim 36.7 \mathrm{Ma}$ (near top C17n.2n to base C16n.2n). Similar to the fourth, the fossil assemblages of the fifth incursion are indicative of shallow marine, near-shore conditions and their widespread distribution across Eurasia suggests that the marine connection to the Western Tethys was maintained. The lack of diachronicity of the fourth incursion between the studied sections across the southwest Tarim Basin suggests the sea entered and withdrew relatively rapidly, as can be expected in the case of eustatic control on a shallow epicontinental basin. However, the westward palaeogeographic step between the fourth and fifth incursions separated by several millions of years rather suggests the combined long-term effect of tectonism, possibly associated with early uplift of the Pamir-Kunlun Shan thrust belt. The fourth and fifth regressions are time-equivalent with significant aridification steps recorded in the Asian interior, thus supporting climate modelling results showing the stepwise sea retreat from Central Asia amplified the aridification of the Asian interior.

Keywords: Eocene; Asia; Tarim Basin; Paratethys Sea; biostratigraphy; palaeogeography.

\section{Introduction}


A vast shallow epicontinental sea extended across Eurasia during the Cretaceous and Paleogene from Europe to the Tarim Basin in western China, before it retreated westward and isolated as the Paratethys Sea in the Oligocene, of which nowadays only the Caspian and Black Seas remain (e.g. Báldi, 1984; Rusu, 1985; Tang et al., 1989; Dercourt et al., 1993; Lan and Wei, 1995; Burtman et al., 1996; Robinson et al., 1996; Rögl, 1999; Burtman, 2000; Popov et al., 2004; Schulz et al., 2005; Vincent et al., 2005; Allen and Armstrong, 2008; Bosboom et al., 2011). The timing and palaeogeography of the long-term westward retreat of the proto-Paratethys Sea are however still poorly constrained and hamper understanding of the mechanisms controlling the sea retreat, as well as its palaeoenvironmental impact on the Eurasian continent. The retreat has originally been attributed to progressive tectonic overthrusting of the Pamir-Kunlun Shan thrust belt in the south and the Tian Shan in the north in response to the Indo-Asia collision (e.g. Hao and Zeng, 1984; Tang et al., 1992; Burtman and Molnar, 1993; Jia et al., 1997; Lan, 1997; Burtman, 2000; Yin and Harrison, 2000; Coutand et al., 2002; Cowgill, 2010). More recently, it has been proposed that fluctuations in the retreat of this sea may have been simultaneously paced by global climate and associated eustatic effects during the shift from greenhouse to icehouse conditions in the late Eocene, culminating at the Eocene-Oligocene Transition (EOT) at $\sim 34$ Ma (e.g. Browning et al., 1996; DeConto and Pollard, 2003; Dupont-Nivet et al., 2007; Zachos et al., 2008; Bosboom et al., 2011; Gasson et al., 2012; Bosboom et al., in press). Climate modelling studies have suggested that the sea functioned as a major moisture source for the Asian continental interior (Ramstein et al., 1997; Zhang et al., 2007), such that its disappearance from Central Asia may have amplified the intensification of the Asian monsoons and the Asian aridification (Bosboom et al., 2011; Bosboom et al., in press). An opportunity to further test these hypotheses is provided by the Cretaceous and Paleogene marine records of the easternmost extent of this sea in the Tarim Basin. These deposits indicate a peculiar pattern of five successive marine incursions, i.e. after the maximum extent reached during the third transgression, the sea retreated stepwise westward paced by the fourth and fifth transgressions (Tang et al., 1989; Lan and Wei, 1995). Using integrated bio-magnetostratigraphy our previous study focused on the Aertashi, Kezi and Keliyang sections along the West Kunlun Shan (Fig. 1) and showed that the sea completely 
withdrew from the palaeodepocenter of the southwest depression after the fourth regression at $\sim 41 \mathrm{Ma}$ (base C18r; Bosboom et al., in press). This new study aims to extend the established chronological framework of the stepped westward retreat by more accurate biostratigraphic dating of the succeeding fifth and last regression from the Tarim Basin at the Bashibulake Mine section along its westernmost margin (Fig. 1), in order to discuss the long-term palaeogeographic dynamics of the proto-Paratethys Sea with respect to early tectonic uplift of the Tibetan Plateau, regional palaeoenvironmental changes in the Asian interior and the deterioration of global climate in the late Eocene.

\section{Geological setting}

The Tarim Basin is part of a relatively undeformed crustal block within the Indo-Asia collision system (e.g. Yin and Harrison, 2000). The sedimentary infill on top of the oceanic crustal basement is primarily composed of Palaeozoic and Mesozoic clastic sediments, which were folded by successive distal accretion of continental terranes along the southern margin of Asia from the late Triassic until the Eocene Indo-Asia collision at 50 Ma (Tian et al., 1989; Hendrix et al., 1992; Yin and Harrison, 2000; Robinson et al., 2003; Jia et al., 2004; van Hinsbergen et al., 2012). Marginal overthrusting and tectonic loading of the Tian Shan, the Pamir Mountains and the Kunlun Shan by the Cenozoic northward movement of India into Eurasia, probably initiated the Late Cretaceous formation of two major distal foreland basins, the Kuche depression along the southern margin of the Tian Shan and the southwest depression along the West Kunlun Shan with its palaeodepocenter near Yarkand (Fig. 1; Burtman and Molnar, 1993; Jia et al., 1997; Yin and Harrison, 2000; Yang and Liu, 2002; Cowgill, 2010). A period of relative tectonic quiescence followed with successive shallow marine incursions in the two depressions. This study focuses on the marine history of the westernmost margin of the Tarim Basin, part of the southwest depression and situated were the present-day Kunlun Shan and Tian Shan meet (Fig. 1).

Marine deposition in the underfilled southwest depression supposedly initiated in the Cenomanian, though marine trace fossils have been described from Barremian to Albian sediments (Guo, 1991; Lan and Wei, 1995). The sea entered the Tarim Basin from neighbouring basins west of the present-day 
Alai Valley (Tang et al., 1992; Burtman and Molnar, 1993; Burtman, 2000). The marine deposits are typical of a shallow and proximal marine environment characterized by distinct fossil assemblages of mostly bivalves, ostracods, dinoflagellate cysts and calcareous nannofossils, enabling inter- and intrabasin stratigraphic correlations (e.g. Mao and Norris, 1988; Tang et al., 1989; Lan and Wei, 1995; Yang et al., 1995; Bosboom et al., 2011; Bosboom et al., in press). Strong similarities between fossil assemblages from the Tarim Basin, Central Asia and Europe indicate that the sea extended across a major part of Eurasia and was connected to the Tethyan Realm (Mao and Norris, 1988; Dercourt et al., 1993; Rögl, 1999; Popov et al., 2004; Bosboom et al., 2011). A total of five marine incursions corresponding to third-order sea-level cycles (sensu Vail and Mitchum Jr, 1979) have been recognized in the Cretaceous-Paleogene sedimentary record of the Tarim Basin, of which the third marine incursion is considered the largest as it extended into the central Maza Tagh range, the northern Kuche Depression and Lop along the south-eastern margin (Fig. 2; Tang et al., 1989; Lan and Wei, 1995; Burtman et al., 1996; Burtman, 2000). Our previous work studied the Aertashi, Kezi and Keliyang sections along the West Kunlun Shan (Fig. 1) and focused on the major fourth incursion near the palaeodepocenter of the southwest depression of the Tarim Basin, showing that the associated sea retreat at $\sim 41 \mathrm{Ma}$ (base $\mathrm{C} 18 \mathrm{r}$; Bosboom et al., in press) is concomitant with the onset of aridification in the Asian interior and East Asian monsoonal intensification and with closure of the Turgai Strait (Akhmetiev and Beniamovski, 2006; Akhmetiev, 2007; Iakovleva and Heilmann-Clausen, 2010; Quan et al., 2011; Bosboom et al., 2014). This study intends to provide precise age control by biostratigraphic dating of the succeeding fifth transgression from the Tarim Basin, which has not been recognized in the previously studied sections along the West Kunlun Shan (Bosboom et al., 2011; Bosboom et al., in press). Previous biostratigraphic studies on the fifth incursion have only documented its marine deposits along the westernmost margin of the basin, west of Kashgar, and have assigned widely differing ages ranging from late Eocene to late Oligocene (Fig. 1; Hao and Zeng, 1984; Mao and Norris, 1988; He, 1991; Zhong, 1992; Lan and Wei, 1995; Yang et al., 1995; Lan, 1997).

After the fifth regression, deposition is exclusively continental without any sedimentary evidence for marine deposition. However, it has been proposed that brackish-marine conditions may have 
occasionally reoccurred up into the Miocene as indicated by foraminifera and ostracod findings, and stable isotope excursions (Zheng et al., 1999; Gao et al., 2000; Jia et al., 2004; Graham et al., 2005; Ritts et al., 2008; Kent-Corson et al., 2009; Zhuang et al., 2011). The reappearance of marine waters in the Tarim Basin during the Miocene is, however, disputable as the foraminifera may have adapted to a non-marine saline lake environment or are an allochthonous eolian deposit (Ye et al., 1996). The possibility of Miocene incursions will be further addressed in the discussion.

Marine deposits predate rapid regional uplift and topographic expression of the Pamir-Kunlun system, occurring in the late Oligocene-early Miocene at $\sim 25-18$ Ma based on sedimentologic, stable isotope and provenance, thermochronologic, palaeomagnetic, and backstripping data (Thomas et al., 1994; Sobel and Dumitru, 1997; Burtman, 2000; Jolivet et al., 2001; Yang and Liu, 2002; Yin et al., 2002; Amidon and Hynek, 2010; Bershaw et al., 2012). However, evidence for initial earlier uplift of the Kunlun Shan is sparse and not well constrained (Jolivet et al., 2001; Yin et al., 2002; Graham et al., 2005; Kent-Corson et al., 2009; Amidon and Hynek, 2010; Clark et al., 2010; Cowgill, 2010). Directly north of the study area, thermochronologic dating in the Kashi Basin (north of Kashgar) and the Kyrgyz Alai Valley indicate exhumation by reactivation of late Palaeozoic thrust structures in the Tian Shan commenced near the Oligocene-Miocene boundary at 24-22 Ma, but southward propagation reached the Kashi Basin-bounding thrust not until 19 Ma (Sobel et al., 2006; De Grave et al., 2012; Yang et al., in press). Consequently, proximal foreland depressions developed during the Neogene along the margins of the Tarim Basin and experienced rapid accumulation of coarse-grained clastics. The Neogene sediments have been weakly deformed by basinward thrusting and overloading of the Kunlun Shan and Tian Shan, which is ongoing until today in response to the continuous northward movement of India into Eurasia.

\section{Lithostratigraphy of sampled sections}

In this study the lithostratigraphic nomenclature used in Bosboom et al. is applied (Fig. 2; 2011; in press). The marine succession of Paleogene age is referred to as the Kashi Group, which comprises in 
chronological order the Aertashi, Qimugen, Kalatar, Wulagen and Bashibulake Formations. The overlying continental Wuqia Group consists of the Kezilouyi, Anjuan and Pakabulake Formations.

Our previous work at the Aertashi, Kezi and Keliyang sections focused on the Kalatar and Wulagen Formations, which are associated to the fourth marine incursion (Figs. 1, 2 and 4). Herefocus is on the Bashibulake Mine section $\left(39^{\circ} 51^{\prime} \mathrm{N}, 74^{\circ} 32^{\prime} \mathrm{E}\right)$ situated at the western margin of the Tarim Basin (Figs. 1, 3 and 4). The last marine sediments should belong to the Bashibulake Formation, corresponding to the fifth transgression, which according to previous studies of macrofossil fauna was limited to the area west of Kashgar (Lan and Wei, 1995; Lan, 1997). The section is named after a nearby mine and complements the previously established stratigraphic framework of the fourth transgression in the southwest depression of the Tarim Basin (Bosboom et al., 2011; Bosboom et al., in press). The strata are exposed continuously in a tributary valley with consistent homoclinal $\sim 75-80^{\circ}$ ENE dip. The Bashibulake Mine section is close or identical to the Bashibulake section which has been part of earlier biostratigraphic studies by Lan and Wei (1995), Lan (1997), Mao and Norris (1988) and Tang et al. (1989). The stratigraphic thicknesses of the recognized lithostratigraphic units were measured to decimetric precision. Zero meter level is defined by the uppermost shell bed.

Here the lithostratigraphy and lithofacies are analysed by comparison to previous lithostratigraphic descriptions and to our previous stratigraphic framework of the fourth transgression in the southwest depression (Fig. 4; Mao and Norris, 1988; Tang et al., 1989; Ye et al., 1996; Jia et al., 2004; Bosboom et al., 2011; Yang et al., 2012; Bosboom et al., in press). These stratigraphic correlations will be assessed in light of biostratigraphic constraints from samples collected at the Bashibulake Mine section.

The basal unit is a distinct resistant interval of grey (oolithic) pack- and grainstones interbedded by green mudstones and marls (base to $-250 \mathrm{~m}$ level). The deposits are exceptionally rich in bivalves (in particular oysters) and are correlated to the previously described Kalatar Formation, which was interpreted to represent an intertidal carbonate shoal and mudflat environment (Bosboom et al., 2011; Bosboom et al., in press). The overlying unit comprises greyish-green mudstones interbedded with fine (bioturbated) sandstones rich in bivalves ( -250 to $-222 \mathrm{~m}$ level). These characteristics are typical of the deposits of the Wulagen Formation, which have previously been interpreted as sub- to intertidal 
mudflat deposits (Bosboom et al., 2011; Bosboom et al., in press). The next unit constitutes massive evaporite beds with a green mud matrix ( -222 to $-198 \mathrm{~m}$ level) and has not been recognized near the palaeodepocenter of the southwest depression, but fits the lithostratigraphic descriptions given in previous biostratigraphic studies of the westernmost Tarim Basin margin and is referred to as the upper part of the Wulagen Formation, the lowest member of the Bashibulake Formation or as a separate formation (Mao and Norris, 1988; Lan, 1997). This evaporite unit is interpreted as representing a supratidal (salt) mudflat environment. Dark red mudstones intercalated with siltstones, occasional bluish grey marls and evaporite nodules constitute the overlying unit (-198 to $-150 \mathrm{~m}$ level) and are interpreted as inter- to supratidal mudflat deposits. The dark-red siltstones and fine sandstones above are typical of a fluvial depositional environment and characterized by trough-cross-bedding, ripple marks and occasional channels which have NNE to NE palaeoflow directions (-150 to $-110 \mathrm{~m}$ level; Fig. 3a and 3b). The clastic beds are replaced by red-brown mudstone alternating with bluishgrey marly mudstones and muddy packstones rich in shells (-110 m level $-5 \mathrm{~m}$ level; Fig. 3c), which are indicative of a sub- to intertidal mudflat environment. Upward red-brown siltstones and fine sandstones reoccur as intercalated beds in red-brown mudstone, initially containing shells, wave ripple marks and nodular evaporite beds ( $-5 \mathrm{~m}$ level to $24 \mathrm{~m}$ level). This alternation of shallow marine mudstones and fluvial sandstones is typical of the Bashibulake Formation. The gradual increase in clastic input records the actual regression, suggesting there is no major unconformity associated to the sea retreat. However, an abrupt shift to continental clastic deposition occurs in the upper part of the section (24 m level to top). Here recurrent (slumped) coarse-grained incised channel beds with gravel lag, characteristic of the continental Kezilouyi Formation, suggest a disconformable contact.

In summary, preliminary facies analyses indicate that the lithostratigraphy constitutes two shallowing-upward cycles typical for shallow epicontinental seas (Figs. 3d and 4; Van Wagoner et al., 1988; Aigner et al., 1990). The lower cycle constitutes the marine Kalatar and Wulagen Formations associated to the fourth transgression and can be recognized across the entire southwest depression of the Tarim Basin. The regression is well-preserved in the sedimentary succession overlying the last fully marine deposits, constituting supratidal evaporite beds and fluvial sandstone channel beds (from 222 to $-149 \mathrm{~m}$ level). The upper cycle is recorded in the members of the Bashibulake Formation 
associated to the fifth transgression, which marks the permanent retreat of the proto-Paratethys Sea from the Tarim Basin. The associated shallowing-upward trend after the uppermost marine shell bed is illustrated by the increasingly dominant presence of oxidized wave-reworked sandstones and evaporite beds (from -5 to $-24 \mathrm{~m}$ level), but abruptly interrupted by erosive fluvial gravel beds at the top (from 24 to $44 \mathrm{~m}$ level). The alternation of siliciclastic and carbonate deposits suggests that superimposed on the overall shallowing-upward trend, high-frequency fluctuations in relative sea level, local climate and sediment supply result in lowstand/wet siliciclastic shedding and highstand/dry carbonate build-up (Budd and Harris, 1990; Reading, 2006).

\section{Biostratigraphy}

In order to improve age control on the two marine incursions recognized in the Bashibulake Mine section, samples were collected from representative marine beds throughout the Kalatar, Wulagen and Bashibulake Formations for foraminifer, ostracod, mollusc, calcareous nannofossil and organic-walled dinoflagellate cyst (dinocyst) analyses (Fig. 4). Age correlations are primarily based upon the standard macro- and microfossil zonations of the geologic time scale by Gradstein et al. (2012).

\subsection{Ostracods}

Twelve samples of approximately $300 \mathrm{~g}$ each collected from the Bashibulake Mine section were analysed for ostracods. After the complete drying of sediments in order to eliminate interstitial water, a sodium sulphate solution $\left(\mathrm{Na}_{2} \mathrm{SO}_{4}\right.$ - Glauber's salt) was used, followed by several freeze-defrost cycles. Finally, samples were washed through a 250 mesh $(0.63 \mathrm{~mm})$ sieve. Ostracod species were picked up and identified with a ZEISS - GSZ binocular microscope. Photographs were taken using a Philips XL 30 Scanning Electron Microscope at Utrecht University.

The ostracods are generally poorly to modestly preserved, as often the ornamentation features are partially dissolved or eroded, probably by transportation or reworking (Fig. 4), which complicates taxonomic identification. Taxonomy is largely based on key standard reference studies, in particular from western Europe (Oertli and Key, 1955; Oertli, 1956; Keij, 1957; Ducasse, 1969; Pietrzeniuk, 
1969; Szczechura, 1977; Keen, 1978; Ducasse et al., 1985a; Ducasse et al., 1985b; Picot, 2002;

Olteanu, 2006; Lord et al., 2009; Pirkenseer and Berger, 2011). Note that the age range given for most of the identified species largely differs in those reference studies.

Micropalaeontological samples from the lower part of the Bashibulake Mine Section, which has been correlated to the Kalatar and Wulagen Formations, are almost barren. Few badly preserved specimens of Leguminocytheries, Cytheridea and Cytherella genera were recognized without being able to indicate theirs specific affiliation. These specimens are generally indicative of shallow marine conditions and do not allow giving a more precise geological age than broadly Eocene. The sample at $224 \mathrm{~m}$ level is particularly rich in coprolites and small sized Cytheridea sp., suggesting restrictive lagoonal conditions in agreement with the directly overlying saline lake deposits.

By contrast, the marine ostracod fauna of the upper marine part, which has been correlated to the Bashibulake Formation, are relatively well-preserved. The Cytherellidae family is well-represented by at least three species: Cytherelloidea ex. gr. dameriacensis, Cytherella compressa and possibly $C$. beyrichi with less visible ornamentation. C. ex. gr. dameriacensis is known from middle and upper Eocene deposits of the Paris and Aquitane Basins in France and the upper Brackleshman Beds of Lutetian age in southern England (Apostolescu, 1955; Keen, 1978; Ducasse et al., 1985b). C. compressa represents a widely recorded species from Eocene deposits of Belgium, southern England, Germany and Poland and Oligocene strata of Belgium, the Netherlands, Hungary, Germany and the Transylvanian Basin of Romania (Keij, 1957; Haskins, 1967; Pietrzeniuk, 1969; Szczechura, 1977; Keen, 1978; Uffenorde, 1986; Monostori, 2004; Olteanu, 2006). This species is considered to live in normal salinity conditions from shallow low energy waters to the infralittoral zone from 0 to $150 \mathrm{~m}$ water depth with its main occurrence around 25 m water depth (Uffenorde, 1986; Keen, 1989).

The Cytheretta genus is common in all samples from the Bashibulake Formation and the following three species have been identified: Cytheretta ex. gr. eocaenica, C. ex. gr. elegans and C.(Flexus?) ex. gr. vulgaris var "tricostulée". Cytheretta eocaenica has been reported from the Eocene of the Paris Basin in Belgium and France, from the upper Eocene of Poland and from the lower Oligocene of the northern Aquitanian Basin (Keij, 1957; Ducasse, 1969; Pietrzeniuk, 1969; Ducasse et al., 1985a; Ducasse et al., 1985b). C. vulgaris is described from middle to upper Eocene beds in the Aquitanian 
Basin (Ducasse, 1969; Ducasse et al., 1985a; Ducasse et al., 1985b). Cytheretta vulgaris var "tricostulée" has been described from sediments of the Medoc (Gironde) area in south-western France corresponding to a regressive phase at the base of the upper Eocene and the first transgressive phase of the lower Oligocene.

The Cytherideidae ostracod family is represented by Cytheridea eocaenica, $C$. sandbergeri, $C$. ex. gr. pernota, Haplocytheridea ex. gr. curvata and Schuleridea perforata. C. eocaenica is described from the upper Eocene of Poland and also mentioned in the Oligocene of southern Romania (Pietrzeniuk, 1969; Olteanu, 2006). C. sandbergeri, sometimes difficult to separate from C. pernota, is recorded in Rupelian deposits from the upper Rhine Graben, the Hessian Depression and the Swiss Jura Molasse (Oertli and Key, 1955; Malz, 1962; Kammerer, 1993; Pirkenseer and Berger, 2011). C. pernota is mainly mentioned from the lower Oligocene of western Europe, but there exists considerable confusion concerning its correct identification. Haplocytheridea ex. gr. curvata (Lienenklaus) was described from lower Rupelian deposits from Sands of Berg and Nucula clay in Belgium (Keij, 1957). S. perforata is a littoral to sublittoral species with a wide regional and stratigraphic distribution, described from the middle Eocene to lower Oligocene from the southern Aquitanian and Paris Basins in France, Belgium, England and Germany, the upper Eocene to lower Oligocene from the Transylvania Basin in Romania and the upper Eocene of Poland (Keij, 1957; Malz, 1962; Ducasse, 1969; Olteanu and Popescu, 1973; Szczechura, 1977; Keen, 1978; Ducasse et al., 1985a; Ducasse et al., 1985b; Olteanu, 2006; Lord et al., 2009).

Pterigocythereis genus is represented by Pterigocyhtereis ceratoptera (Bosquet) mentioned from the upper Rupelian of the upper Rhine Graben, the Oligocene of the Paris Basin and the lower Rupelian from Meeressand-Septarienton groups from the Swiss Jura correlated to zones NP21-22 (Apostolescu, 1962; Ducasse et al., 1985a; Picot, 2002; Pirkenseer and Berger, 2011). This marine genus is used as a fossil marker for water depth, indicating minimum water depth of approximately 60 $\mathrm{m}$ at open marine coasts and less than $10 \mathrm{~m}$ in restricted marine environments (Libeau, 1980; Carbonnel, 1998). However, recent Pterigocytheris jonesii has been observed in the Adriatic Sea up to $242 \mathrm{~m}$ water depth with optimum depths between 80 and $170 \mathrm{~m}$ (Bonaduce et al., 1975). Some specimens also have similarities with the Eocene species Pterigocytheris cornuta. 
Others species commonly recorded in the upper marine part are Eucytherura keiji, Rugieria semireticulata, "Leguminocythereis" sorneana, Echinocythereis? cf. hamsteadensis and Grinionensis ex. gr. triebeli. E. keiji, is described from the upper Eocene of Poland and Germany and the Oligocene of Belgium (Keij, 1957; Pietrzeniuk, 1969; Szczechura, 1977). R. semireticulata is reported from the Bartonian to Priabonian Barton Beds on the Isle of Wight in England, as well as from the Bartonian Barrême syncline in France (Keen, 1978; Apostolescu and Dellenbach, 1999; Lord et al., 2009). L. sorneana is known from the lower Oligocene in the southern upper Rhine Graben, the Swiss Molasse Basin and the Jura Molasse (Oertli, 1956; Picot, 2002; Pirkenseer and Berger, 2011). E. hamsteadensis is mainly a lower Rupelian species recorded from the upper Hamstead Beds on the Isle of Wight (Keen, 1978). G. triebeli is mentioned from the earliest Rupelian of the upper Rhine Graben, from which many ostracods have been recorded in two Rupelian transgression-regression cycles related to the global Ru1 and Ru2-3 sequences (Neal and Hardenbol, 1998; Pirkenseer and Berger, 2011).

Less common species are represented by Loxoconcha ex. gr. nystiana, Cytheromorpha cf. zinndorfi and Paijenborchella tricostata. L. nystiana occurs from late Eocene to Oligocene and presents large variations in both size and ornamentation due to the palaeoenvironmental conditions, in particular water chemistry (Keen, 1978; Pirkenseer and Berger, 2011). This species is described as Loxoconcha favata from the lower Rupelian of the Swiss Jura (Picot et al., 2008). C. zinndorfi is widely recorded from the lower Oligocene of western Europe to Turkey (Keij, 1957; Sönmez-Gökçen, 1973; Keen, 1978; Keen, 1989; Lord et al., 2009; Pirkenseer and Berger, 2011). Recent Cytheromorpha species (C. nana) reported from the Adriatic Sea are living in coastal areas up to $120 \mathrm{~m}$ water depth (Bonaduce et al., 1975), whereas the Paleogene species appears to occur in meso- to polyhaline coastal waters (Kammerer, 1993).

Summarizing, most ostracod species from the Bashibulake Formation have a stratigraphic range from middle-late Eocene to early Oligocene and are indicative of littoral to sublittoral, shallow marine conditions. The identified species appear to correspond to the ostracod assemblages described from the Wulagen and Bashibulake Formations by Ye et al. (1996), despite their different usage of names (primarily based on the Russian literature of Mandelstam, 1958). 


\subsection{Foraminifera}

One sample from the lower marine part, which has been lithostratigraphically correlated to the Wulagen Formation, contains low numbers of poorly preserved Cibicides species. These are not age diagnostic and may be indicative of an open marine shelf environment.

Six samples from the upper marine part, identified as the Bashibulake Formation, contain moderately to poorly preserved but more diverse foraminifera. Single samples were collected at the 95, -85 and $-55 \mathrm{~m}$ levels, and three samples between the -45 and $-40 \mathrm{~m}$ levels. The upper three samples, just below the $-40 \mathrm{~m}$ level contain low numbers of the planktic species Pseudohastigerina micra. Nocchi et al. (1986) and Wade and Pearson (2008) report collapsing abundance and size reduction (from the fraction $>125 \mu \mathrm{m}$ to $<125 \mu \mathrm{m}$ ) in the genus Pseudohastigerina at the EOT. As in the sampled material the specimens occur in the fraction $>125 \mu \mathrm{m}$, these samples are likely of Eocene age. The low diversity assemblages of smaller benthic foraminifera dominated by Cibicides and Anomalinoides species (among others Cibicides cf. C. tenellus) further suggest a late Eocene age (Murray et al., 1989), which is in agreement with the occurrence of larger-sized P. micra.

The sample at the $-85 \mathrm{~m}$ level is strongly decalcified and dominated by an agglutinated Rheophax species. Agglutinated foraminifera form $45 \%$ of the assemblage at the $-95 \mathrm{~m}$ level, $30 \%$ at the $-85 \mathrm{~m}$ level, and together with Rheophax sp. include Spiroplectinella laevis, Haplophragmoides spp. and Ammobaculites spp.. Less than $10 \%$ of the assemblages in the other samples consist of agglutinated foraminifera. Larger benthic foraminifera, mainly Nummulites spp., are extremely rare.

In summary, the benthic assemblages suggest a late Eocene deposition in a neritic environment. At the $-95 \mathrm{~m}$ level the benthic assemblage is relatively diverse and, together with sparse Melonis barleeanum, Pullenia sp. and Cibicides $\mathrm{cf}$. C. pharaonis, might reflect mid-shelf depth although Haplophragmoides spp. are more common at inner neritic depths. At the $-40 \mathrm{~m}$ level the common occurrence of miliolids, of which some are quite large, indicates a middle- to inner neritic depth, and possibly also a deviating salinity. In addition, fish remains, the occurrence of Bulimina ovata-quadrata and relatively abundant $N$. insecta suggest oxygen depletion at the sea floor.

\subsection{Molluscs}


Oysters (Ostreidae) and scallops (Pectinidae) dominate the mollusc record of the Bashibulake Mine section (Fig 6 and Table DR1). These epibenthic pteriomorph (Pteriomorphia) bivalves produce calcite shells which makes them stable against secondary leaching in carbonate deposits (EstebanDelgado et al., 2008). The occurrence of aragonite secreting molluscs is indicated by few turritelline steinkerns and by drill holes in Platygena shells attributed to boring bivalve Lithophaga sp.. Our taxonomic identifications are presented in stratigraphic upward order through the Bashibulake Mine section, largely following Lan and Wei (1995) and Lan (1997), representing the most recent revision of regional systematic literature.

The common, monospecific occurrence of Ostrea (Turkostrea) cizancourti in the lowermost part of the section points to stratigraphic position in the top of the Kalatar Formation (Lan, 1997), which has been assigned a Lutetian age (Bosboom et al., in press). This small-sized species indicates fully marine, shallow water littoral environment. Its common presence in contemporaneous deposits in the regional Alai stage in the Ferghana and Afghan-Tajik Basins (Berizzi Quarto di Palo, 1970), points to well-established connections to the open sea. The presence of Ostrea (Turkostrea) striplicata in the lowermost part of this interval is tentatively indicated by one large-sized, but badly preserved specimen.

The two samples from the overlying unit bear oysters Sokolowia buhsi, Kokanostrea kokanensis and Flemingostrea kaschgarica and the scallop Palliolum trigintaradiatum, which are all characteristic of the Wulagen Formation and in line with previous results from the previously studied sections in the southwest depression (Lan and Wei, 1995; Lan, 1997; Bosboom et al., 2011; Bosboom et al., in press). This Sokolowia-Kokanostrea assemblage characterizes in particular the lower and the middle part of the formation and has been attributed a late Lutetian age (Lan, 1997; Bosboom et al., in press). It points to normal saline, warm and turbulent, subtidal shallow marine water conditions. The well-connected, open marine setting is indicated by the palaeobiogeographic distributional patterns of the fauna. In particular Sokolowia buhsi shows extraordinary wide dispersal in the regional Turkestan stage of Central Asia in northwest Afghanistan and in northern Iran and its occurrence has even been reported from lowermost Bartonian strata of the Transylvanian basin (Grewingk, 1853; Vialov, 1937; Berizzi Quarto di Palo, 1970; Rusu et al., 2004). Beyond that, the scallop Palliolum trigintaradiatum 
has been found still further west, in Lutetian beds of the Bracklesham Bay in Great Britain (Wood, 1861). The Ostrea ulugqatica assemblage described by Lan (1997) from the uppermost part of the Wulagen Formation is absent in the Bashibulake Mine section.

Following an interval of 180-m thickness without any mollusc record, the subsequent marine transgression brings a complete overturn of mollusc fauna. The complete succession of biostratigraphic horizons described from the Bashibulake Formation by Lan (1997) is represented. The Bashibulake fauna has not been encountered in our previous studies of the fourth transgression near the palaeodepocenter of the southwest Tarim depression (Bosboom et al., 2011; Bosboom et al., in press), which is in agreement with previous mollusc studies (Lan and Wei, 1995; Lan, 1997). Two lowermost samples comprise Platygena asiatica, which is a large, thick-walled, shallow water, sediment incliner and marker of the Platygena-Pholadomya assemblage in the second and third members of the Bashibulake Formation (Lan, 1997). Its shells are secondarily bio-eroded by the boring bivalve Lithophaga sp., likely pointing to very shallow, fully marine littoral environment. Following a bed with common serpulid and balanid remains, the middle part of the interval is marked by the presence of large-sized Ferganea bashibulakeensis, a marker species of the FerganeaLithophaga assemblage of the third and fourth members of the Bashibulake Formation. Small-sized Ferganea ferganensis and Ferganea sewerzowii are likely present therein. Together with Lithophaga sp. borings and the scallop Palliolum minblaki, these molluscs mark fully marine, subtidal, shallow water conditions. Finally, the common occurrence of Cubitostrea tianschanensis in the topmost sample indicate the installation of Cubitostrea-Ferganea sewerzowii assemblage characteristic of the fourth and fifth members of the Bashibulake Formation, indicating an intertidal environment within hypersaline lagoonal facies (Lan, 1997). The overall faunal composition with endemic taxa such as Ferganea or Cubitostrea tianschanensis, known only from the Tarim, Ferghana and Afghan-Tajik Basins, reflects the progressive basinal restriction marking the onset of the last regressive event when the sea gradually retreated from this region (Lan, 1997).

In summary, the Bashibulake fauna indicates a progressive shift from fully open to more restricted conditions. It points to a Priabonian age, fixed by the correlation with the uppermost marine deposits 
of the late Priabonian Sumsar Formation in the Ferghana Basin in Kyrgyzstan (nannoplankton zones NP19-NP20; Lan and Wei, 1995; Muzylev et al., 1996).

\subsection{Calcareous nannofossils}

The preparation followed standard techniques by Bown and Young (1998) and analyses were performed with a light microscope at 1200x magnification along two transverses of the slide, and sometimes extended at 400x in search of rare biomarkers. The biostratigraphic attribution is primarily based on the standard zonations (Okada and Bukry, 1980; Gradstein et al., 2012). In general, nannofossil abundance and preservation in the collected samples are very limited, which could be indicative of a near-shore environment (Fig. 7 and Table DR2).

The lowermost fossiliferous sample at $-247 \mathrm{~m}$ level in the lower marine part, correlated to the base of the Wulagen Formation, contains a nannofossil assemblage that is generally characteristic of the middle Eocene. The absence of Reticulofenestra umbilicus may indicate a late Lutetian age. The sporadic presence of Lanternithus arcanus in the same sample may further constrain this age by correlation to Zone CP13c (equivalent to NP15c of Martini, 1970) as suggested by Bown (2005). This age assignment is consistent with the age of the lower part of the Wulagen Formation and the upper part of the Kalatar Formation in the previously studied Aertashi, Kezi and Keliyang sections of the southwest Tarim Basin (Fig. 1; Bosboom et al., in press), where rare L. arcanus were recorded without R.umbilicus. The rare nannofossils indicate a near-shore environment.

From the overlying 180-m-thick interval seven samples have been examined which are completely barren. As calcareous phytoplankton requires clear waters to thrive and prefers open marine conditions, the interval lithostratigraphically correlated to the upper part of the Wulagen Formation and lower part of the Bashibulake Formation, records a sea-level lowstand in this part of the basin, which would correspond to the last major sea retreat recorded in the southwest Tarim Basin near the palaeodepocenter (Bosboom et al., in press). The age of this interval is not precisely identifiable by means of nannofossils, but should be younger than the first occurrence (or lowest occurrence) of $R$. umbilicus, as it has been previously identified in the underlying Wulagen Formation in the southwest Tarim Basin and should therefore correspond to Zone CP14 (Bosboom et al., 2011). 
At $-57 \mathrm{~m}$ level the reappearance of nannofossils by the presence of Cribrocentrum reticulatum suggests the age is not older than Bartonian. Although, the distribution of $C$. reticulatum has been matter of debate, in particular its first occurrence (see Fornaciari et al., 2010 and references therein), it can be conservatively restricted to an interval corresponding to the middle part of magnetochron $\mathrm{C} 18 \mathrm{r}$ up to the base of C15n. A correlation to an interval above its Lowest Common Occurrence (sensu Fornaciari et al., 2010), which is used as a reliable biomarker for the Bartonian, is further suggested by C. reticulatum being relatively more abundant and well-preserved in the sample at the $-49 \mathrm{~m}$ level with moderate to good preservation. The relatively good preservation and common presence of the nannofossil assemblage indicate more open marine conditions for the upper marine part of the section correlated to the Bashibulake Formation (from -57 to 0 m level).

In general, the encountered nannofossil assemblage in the Bashibulake Formation correlates to Zones CP14b-CP15a. The absence of the genus Neoccolithes, which last occurrence is reported at the base of CP15a, can further refine this correlation to Zone CP15a.

This correlation is further supported by studies of Zhong (1992) and Ye et al. (1996) reporting in a few samples from the second to fourth members of the Bashibulake Formation the rare presence of Ismolithus recurvus, which has its first occurrence at the top of subzone CP15a (top C17n1n), although the samples did not yield any Ismolithus recurvus most likely due to the relatively low sampling-resolution in the Bashibulake Formation and the poor preservation of the assemblage.

Accordingly, the Bashibulake Formation has a younger age than that assigned to the underlying Wulagen Formation correlated to Zone CP14 (Bosboom et al., in press), which is in agreement with the age assigned by Zhong (1992) to the first and second members of the Bashibulake Formation. The assemblage is generally characteristic of mid-latitude water masses. The relatively common abundance of holococcoliths like Transversopontis pulcheroides and Lanthernithus spp. indicates a near-shore environment.

\subsection{Palynology}

Twenty samples have been processed for palynological analyses, from which nine samples were either barren or the preservation state was insufficient to identify species on a genus level. The 
preparation followed standard palynological techniques as described in Houben et al. (2011).

Taxonomy follows that cited in Fensome and Williams (2004).

The recovered palynological assemblages from the lower and upper marine unit are characterized by abundant dinocysts and yield typically low amounts of terrestrial palynomorphs (Fig. 8 and Table DR3). The upper marine unit has some marked elevated abundances (up to 30\%) of the marine green algae Tasmanites spp. The regressive interval of gypsum and coarse-grained clastics between the two marine incursions is palynologically barren.

The presence of the dinocyst species Aerospharidium diktyoplokum, Charlesdowniea wulagenensis and Rhombodinium draco imposes a close correspondence of the lower marine unit to the Turbiosphaera filosa Zone of Mao and Norris (1988) and to the previously studied marine deposits of the Kalatar and Wulagen Formations at the Aertashi, Kezi and Keliyang sections in the southwest Tarim Basin, which have previously been assigned a Lutetian age (Fig. 1; Bosboom et al., 2011; Bosboom et al., in press). The marine mud bed at level $-247 \mathrm{~m}$ in the Bashibulake Mine section is tentatively correlated to magnetochron C19n, based upon the First Occurrence (FO) of $R$. draco (Iakovleva and Heilmann-Clausen, 2010). This corroborates with the lithostratigraphic correlation of these lower marine sediments to the Kalatar and Wulagen Formations (Bosboom et al., in press).

The samples of the upper marine part (-108 to $0 \mathrm{~m}$ level), lithostratigraphically correlated to the Bashibulake Formation, hold many different dinocyst species, including Cordosphaeridium funiculatum. Since C. funiculatum occurs rather consistently in the Bashibulake Formation, its FO there is tentatively correlated to the consistent occurrence of $C$. funiculatum in southwest Siberia within magnetochron C17n (Iakovleva and Heilmann-Clausen, 2010). The FO of Lentinia serrata at the $-108 \mathrm{~m}$ level supports this correlation, as the FO of $L$. serrata and the consistent occurrence of $C$. funiculatum are almost synchronous in southwestern Siberia. Furthermore, the FOs of Charlesdowniea coleothrypta subsp. rotundata sensu De Coninck (1986), Glaphyrocysta microfenestrata and Thalassiphora reticulata in the upper part of the record (-38 to $0 \mathrm{~m}$ level) are in perfect agreement with the southwest Siberian and Danish records (Heilmann-Clausen and Van Simaeys, 2005; Iakovleva and Heilmann-Clausen, 2010). Using the FO of these species, the top of the upper marine interval is bracketed between the base of magnetochron C16n.1n and the base of C15n. Summarizing, 
the marine beds of the last transgression at the Bashibulake Mine Section are tentatively correlated to the latest Bartonian-early Priabonian from $~ 38.4$ (base C17n.3n) to 35.3 Ma (base C15n; Fig. 4).

The recovered dinocyst assemblages generally lack dinocysts species that are typically associated with more open marine conditions, such as Impagidinium spp. Most assemblages are dominated by outer neritic species, such as Spiniferites spp. and Areosphaeridium diktyoplokum (Brinkhuis, 1994; Powell et al., 1996). In total, three periods of restricted marine 'lagoonal' conditions have been recorded by elevated abundances of goniodomid taxa, in particular Homotryblium spp. The red coloured coarse-grained clastics situated between the lower and upper marine unit are barren, which is in agreement with the supposed drop in water level. The marine conditions re-establish upwards with a minor peak in Impagidinium spp. at level -82 m marking the most open marine conditions during the studied interval. The successive peaks of Adnatosphaeridium (outer neritic), Glaphyrocysta (inner neritic) and finally Homotryblium (restricted marine) impose a shallowing trend and a more proximal setting towards the end of the record (Pross and Brinkhuis, 2005).

\section{Discussion}

\subsection{Timing, palaeoenvironment and palaeogeography of the sea retreat}

\subsubsection{Fourth incursion}

The studied dinocyst, calcareous nannofossil, mollusc, ostracod and foraminifera assemblages of the lower marine incursion at the Bashibulake Mine section confirm correlation to the Kalatar and Wulagen Formations. This, our previous study of marine deposits of the fourth incursion along the West Kunlun Shan and the regional compilation of reports of the distribution of these formations (Bosboom et al., 2011; Bosboom et al., in press), clearly illustrates that the fourth and last major incursion into the Tarim Basin reached across the entire southwest depression (Figs. 1 and 9). At the Bashibulake Mine section the Wulagen Formation is thinner in comparison to the Kezi, Aertashi and Keliyang sections and saline lacustrine evaporite beds are dominant, which is in agreement with the Bashibulake Mine section being located farther from the depocentre (Figs. 1 and 4; Jia et al., 1997; 
Yang and Liu, 2002). Our biostratigraphic analyses consistently point to a Lutetian age for the marine deposits of the fourth transgression at the Bashibulake Mine section, which is in perfect agreement with the latest Lutetian-earliest Bartonian age of the sea retreat by integrated bio-magnetostratigraphic dating of the marine-continental transition at sections near the palaeodepocenter of the southwest depression ( 41 Ma; base C18r; Bosboom et al., in press).

\subsubsection{Fifth incursion}

The encountered fossil assemblages of the upper marine part corroborate the lithological correlation to the Bashibulake Formation and thus confirm that the uppermost marine sediments at the westernmost margin of the Tarim Basin correspond to the fifth transgression. Our biostratigraphy indicates a late Bartonian-Priabonian age range for the marine sediments of the Bashibulake Formation, which significantly narrows the previous late Eocene-late Oligocene age range based upon foraminifera, ostracods, bivalves, calcareous nannofossils and dinoflagellate cysts (Hao and Zeng, 1984; Mao and Norris, 1988; He, 1991; Zhong, 1992; Lan and Wei, 1995; Yang et al., 1995). Careful evaluation of the acquired biostratigraphic ages for each fossil group leads us to assign an age ranging from base $\mathrm{C} 17 \mathrm{n} .3 \mathrm{n}$ to base $\mathrm{C} 15 \mathrm{n}$ for the marine deposits of the fifth transgression. Relying on the small age range given by correlation to calcareous nannofossil Zone CP15a, the best age estimate ranges from near top C17n.2n to base C16n.2n. Accordingly, the uppermost age-diagnostic fossil found at level $0.0 \mathrm{~m}$ would be older than $\sim 36.7 \mathrm{Ma}$ and the lowermost age-diagnostic fossil at level $-107.9 \mathrm{~m}$ would be younger than $\sim 38.0 \mathrm{Ma}$ (Fig. 4). Chronostratigraphic synthesis of the biostratigraphic results thus constrains the last sea retreat from the Tarim Basin to the early Priabonian, evidently showing that it clearly precedes the major $\sim 70 \mathrm{~m}$ sea-level drop associated to the EOT at 34 Ma (Pekar et al., 2002; Miller et al., 2005; Katz et al., 2008; Lear et al., 2008).

The marine depositional environment of the last and fifth transgression is, like the fourth transgression, characterized by fully marine, shallow water, near-shore conditions with deviating salinity. The stratigraphic succession of the encountered fossil assemblages perfectly illustrates the associated shallowing-upward cycle (Fig. 4) and typical of shallow epicontinental basins. After the uppermost continental sandstone beds at the $-110 \mathrm{~m}$ level rapid deepening occurs, followed by gradual 
shallowing from subtidal facies at outer neritic depth at the $-85 \mathrm{~m}$ level to restricted marine hypersaline lagoonal facies at the $0 \mathrm{~m}$ level.

Our litho-biostratigraphic analyses have improved the age accuracy of the Central Asian sea retreat during the late Eocene. This allows us to further evaluate the palaeogeography, controlling mechanisms and palaeoenvironmental impact of the stepped disappearance of the proto-Paratethys Sea from Central Asia in the Eocene (Fig. 2).

\subsection{Palaeogeographic synthesis}

The maximum third marine incursion, corresponding to the Aertashi and Qimugen Formations, extended farthest eastward into the Tarim Basin and is poorly constrained in age between the late Paleocene and early Eocene (Hao and Zeng, 1984; Mao and Norris, 1988; Tang et al., 1989; Zhong, 1992; Lan and Wei, 1995; Yang et al., 1995; Burtman, 2000). During the subsequent fourth incursion in the Lutetian the sea concentrated mostly in the southwest depression along the West Kunlun Shan as indicated by deposition of the Kalatar and Wulagen Formations (e.g. Hu, 1992; Jia et al., 1997; Yang and Liu, 2002; Jia et al., 2004; Bosboom et al., 2011; Bosboom et al., in press). This study shows that during the last fifth incursion in the latest Bartonian-early Priabonian, the sea was indeed restricted to the westernmost margin of the Tarim Basin. The area west of Kashgar likely formed a separate basin, isolated from the southwest depression of the Tarim Basin (Figs. 1 and 9). Near the palaeodepocenter of the southwest Tarim Basin at the previously studied Aertashi and Kezi sections, the Bashibulake Formation is not observed in age-equivalent stratigraphic intervals (Bosboom et al., 2011; Bosboom et al., in press). There, the marine deposits of the Kalatar and Wulagen Formations associated to the fourth incursion are directly overlain by the continental deposits of the Kezilouyi Formation and hence the marine deposits of the Bashibulake Formation cannot be traced eastward into the southwest depression (Figs. 4 and 9). This is in contrast with several reports arguing for the presence of the Bashibulake Formation in the southwest Tarim Basin, leading to erroneous age determinations and associated interpretations (Wang et al., 2012). Note also that much older early Eocene ages for the sea incursions have recently been proposed based on magnetostratigraphic dating of the Oytag (Wuyitake) section in northwest Tarim (Sun and Jiang, 2012). This discrepancy is clearly 
attributable to the evident lack of continuity of this well-known section, making it unsuitable for magnetostratigraphic analysis (Sobel and Dumitru, 1997; Bershaw et al., 2012).

During the fourth transgression the sea in the Tarim Basin maintained well-established connections to the Western Tethys, as indicated by the close resemblance of the fossil assemblages from the southwest Tarim Basin to those studied in contemporaneous Eurasian basins (Bosboom et al., 2011). This is further corroborated by this study, since the mollusc assemblages collected from the Kalatar and Wulagen Formations at the Bashibulake Mine section have a geographical extend as far west as Backlesham Bay in Great Britain. The palaeogeography of the proto-Paratethys Sea during the succeeding fifth marine incursion was probably comparable, despite that it extended less far eastward into the Tarim Basin. The collected molluscs are common throughout Transcaucasia and Europe, showing the connection with the Western Tethys was maintained and the Eurasian sub-basins remained interconnected as a single unified basin. However, the mollusc species from the assemblage at the top of the Bashibulake Formation are endemic to the Tarim, Ferghana and Afghan-Tajik Basins in Central Asia, likely as a result of their autochthonous evolution under restricted conditions during the last phase of the fifth incursion before the retreat.

After the fifth incursion, the continental Tarim Basin probably remained hydrologically connected to the west until at least the major sea-level drop of the $\sim 34$ Ma EOT, expressed by a major discontinuity in the continental deposits of equivalent age at the Aertashi section in the southwest Tarim Basin (Bosboom et al., in press). This hiatus may correspond to the observed abrupt change in depositional environment and incision observed at the top of the Bashibulake Formation and base of Kezilouyi Formation at the $24 \mathrm{~m}$ level in the Bashibulake Mine section studied here (Fig. 4). The EOT is contemporaneous with the reported isolation and birth of the Paratethys Sea, which supposedly occurred in the latest Eocene or early Oligocene, as shown by the widespread sedimentation of anoxic organic-rich mudstones in basins to the west (e.g. Black Sea and South Caspian Basins; Báldi, 1984; Rusu, 1985; Dercourt et al., 1993; Robinson et al., 1996; Rögl, 1999; Popov et al., 2004; Schulz et al., 2005; Vincent et al., 2005; Allen and Armstrong, 2008; Popov et al., 2008; Johnson et al., 2009).

It is questionable if fully marine conditions re-established in the Tarim Basin after the fifth incursion. This has been suggested based on interpretation of stable isotope excursions and the rare 
occurrences of euryhaline and brackish ostracods and foraminifera in sediments of middle Miocene age (Zheng et al., 1999; Gao et al., 2000; Jia et al., 2004; Graham et al., 2005; Ritts et al., 2008; KentCorson et al., 2009; Zhuang et al., 2011). However, diagnostically marine depositional environments with marine bivalves such as found in the Paleogene have not been reported after the fifth incursion (Ye et al., 1996; Zheng et al., 1999; Jia et al., 2004). Brackish-marine conditions may have been maintained up to the Miocene in isolated restricted basins where former marine species could have adapted to these brackish environments (Ye et al., 1996). Remarkably, Ritts et al. (2008) report wellpreserved planktonic foraminifera typical of open marine conditions from middle Miocene conglomeratic units in the south-eastern margin of the Tarim Basin, while from the sediments of the major and well-established marine incursions of the Cretaceous and Paleogene only rare planktonic taxa have been reported from the westernmost margin of the Tarim Basin (Hao and Zeng, 1984). Based on the complete absence of middle Miocene marine deposits in the neighbouring basins providing potential connection to the global ocean (e.g. Burtman, 2000; Coutand et al., 2002; Popov et al., 2004), combined with the character of the sedimentary facies contrasting open marine conditions, these findings are highly doubtful and need careful consideration before providing proof for postEocene marine flooding of the Central Asian basins.

\subsection{Controlling mechanism}

Our new results corroborate our previous conclusion that the stepwise sea retreat out of the Tarim Basin was likely caused by a combination of long-term aggradational infilling controlled by early Tibetan Plateau uplift and short-term eustatic sea-level fluctuations (Fig. 2; Bosboom et al., in press). For the fourth incursion, the coeval ages of the marine Kalatar and Wulagen Formations between southwest to northwest Tarim suggest that this incursion is not time-transgressive at the age-resolution of the biostratigraphy. Such limited diachronicity indicates the sea entered in and withdrew out of the Tarim Basin relatively rapidly, as can be expected in the case of eustatic control on a shallow epicontinental basin with low gradients, rather than long-term tectonic control. The fourth regression at 41 Ma corresponds in age with the late Lutetian disconnection of the proto-Paratethys Sea from the 
Arctic Sea by closure of the West-Siberian Sea and Turgai Strait (Akhmetiev and Beniamovski, 2006; Akhmetiev, 2007; Iakovleva and Heilmann-Clausen, 2010; Bosboom et al., in press).

The fifth incursion corresponds in timing with reported marine transgressions of Bartonian age followed by early Priabonian regression documented in various European basins, including the Paris Basin, the Ebro Basin, the Transylvanian Basin and the Hampshire Basin (Proust and Hosu, 1996; López-Blanco et al., 2000; Lartaud, 2007; Costa et al., 2010; Dawber et al., 2011). These regionally time-equivalent events suggest eustatic forcing. Global sea-level drops, in the order of 10 to $40 \mathrm{~m}$, have indeed been reported from the early Priabonian around $\sim 37.5$ and $~ 35.5$ Ma (Miller et al., 2005; Kominz et al., 2008). These sea-level fluctuations are contemporaneous with short-term global cooling in the early Priabonian reported from the marine record, as indicated by a positive peak in $\delta^{18} \mathrm{O}$ in the Southern Ocean (named event $\mathrm{C}$ by Villa et al., 2008) and by an elevated $\mathrm{CaCO}_{3}$ interval in the equatorial Pacific (named Carbonate Accumulation Event 5) interpreted as deepening of the calcite compensation depth (CCD) in reaction to cooling (Lyle et al., 2005). Early Priabonian eustatic variations may thus have forced the observed sea fluctuations across the Tarim Basin.

However, the difference in westward palaeogeographic extent between the fourth and fifth incursions separated by several millions of years rather suggests the combined effect of long-term mechanisms such as tectonically controlled sedimentary infilling or diminished subsidence. The reported eustatic sea-level fluctuations from the Lutetian to Priabonian do not show a long-term decreasing trend that would correspond to the observed decrease from the fourth to the fifth incursion (Miller et al., 2005; Kominz et al., 2008). A distal source of infilling sediment is provided to the south by the early uplift of the Pamir and Kunlun Shan thrust belts (Yin and Harrison, 2000; Jolivet et al., 2001; Yang and Liu, 2002; Yin et al., 2002; Graham et al., 2005; Kent-Corson et al., 2009; Amidon and Hynek, 2010), which according to the late Eocene configuration of the Pamir by Cowgill (2010) were situated 100-300 km south of their present-day positions. This is in good agreement with measured northward palaeoflow directions in the continental infill on top of the marine sediments of the fourth marine incursion, both at the Bashibulake Mine section reported here and at the Aertashi section to the west (Bosboom et al., in press). Accordingly, deformation and associated aggradational infilling propagated to the north in relation to the Indo-Asia collision and Pamir indentation, forcing 
the long-term westward sea retreat from the Tarim Basin. This process started from the maximum third incursion in the late Paleocene-early Eocene, coeval with the onset of the Indo-Asia collision. Long-term distal tectonism continued until at least the $\sim 34$ Ma EOT when the Tarim Basin was still hydrologically connected to the Western Tethys and not isolated from basins to the west. The complete closure of the Tarim Basin by the Pamir indentation probably ensued important proximal tectonism in the Western Kunlun Shan and Tian Shan, associated with documented major exhumation and alluvial deposition reported to start only 25-18 Ma (e.g. Sobel and Dumitru, 1997; Sobel et al., 2006; Amidon and Hynek, 2010; 2010; De Grave et al., 2012; Yang et al., in press). This palaeogeographic evolution is generally similar to that recently proposed by Wei et al. (2013). However, they use the highly unlikely Miocene presence of a Tarim Sea connected to the western marine realm to infer the tectonic evolution of the Pamir, based upon a review of previously discussed reports of rare foraminifera from Miocene strata (e.g. Hu, 1982; Ritts et al., 2008).

\subsection{Palaeoenvironmental impact}

To evaluate the potential palaeoenvironmental impacts of the fourth and fifth sea incursions, their established ages can be compared to reported ages of Asian palaeoenvironmental changes. Our previous study has shown that the major fourth sea-level retreat during the latest Lutetian-earliest Bartonian is concomitant with indications of aridification of the Asian continental interior and intensification of the East Asian monsoon (Bosboom et al., in press), which is in agreement with climate modelling studies suggesting that the sea functioned as an important moisture source for the Asian interior (Ramstein et al., 1997; Zhang et al., 2007). The timing of the sea retreat at $\sim 41 \mathrm{Ma}$ is concomitant with an increase in seasonal precipitation in the middle Eocene $(\mathrm{C} 19 \mathrm{r}-\mathrm{C} 18 \mathrm{r})$ recorded in fossil pollen and leaf records in northeast China and regional disappearance of a relatively wet perennial saline lake system and prominent shift to relatively more arid flora around $\sim 41 \mathrm{Ma}(\mathrm{C} 19 \mathrm{n}-$ C18r) recorded in the Xining Basin along the north-western margin of the Tibetan Plateau (Quan et al., 2011; Quan et al., 2012; Bosboom et al., 2014; Bosboom et al., in press). Here, the middle to late Eocene stepwise disappearance of saline lake gypsum beds and shift to relatively arid flora have been accurately linked to both regional biotic turnovers and the deterioration of global climate (e.g. Meng et 
al., 1998; Miller et al., 2005; Zachos et al., 2008; Kraatz and Geisler, 2010; Gomes-Rodrigues et al., 2012), both culminating at the EOT at $\sim 34$ Ma which precisely correlates to the uppermost gypsum bed (top C13r; Dupont-Nivet et al., 2007; Abels et al., 2011). The aridification step at $41 \mathrm{Ma}$ is followed by another significant step recorded at $\sim 37.1 \mathrm{Ma}$ (top C17n.1n), which shows a shift to less stable saline lake systems indicated by a decrease in gypsum relative to mudstone beds and a drastic palynological change (named Step 1 in Figs. 2 and 4; Abels et al., 2011; Hoorn et al., 2012). The coeval timing of the $37.1 \mathrm{Ma}$ aridification step and the continued intensification of the East Asian monsoon system in the late Eocene with the fifth regression (Quan et al., 2011), suggests that the sea in Central Asia may have continued to act as an important moisture source for the Asian continental interior until at least the early Priabonian (Figs. 2 and 4). This aridification step is followed by the major regional Asian aridification at the EOT, which corresponds in age with the major hiatus found in the Aertashi section and possibly with the unconformable contact at the top of the Bashibulake Formation and the base of the Kezilouyi Formation at the $24 \mathrm{~m}$ level in the Bashibulake Mine section studied here. It is possible that the major $\sim 70$ meter eustatic sea-level drop associated with the EOT resulted in another significant westward retreat of the proto-Paratethys Sea in Central Asia (Pekar et al., 2002; Miller et al., 2005; Katz et al., 2008; Lear et al., 2008), although its palaeogeographical distribution at that time is uncertain. A major negative isotopic shift from Eocene to Oligocene reported from the Tarim Basin and northern Tibetan Plateau by Graham et al. (2005) has been attributed to aridification in response to early development of Tibetan topography after the Indo-Asia collision (e.g. Rowley and Currie, 2006; Dupont-Nivet et al., 2008; Wang et al., 2008; Dai et al., 2013). A Paleogene decrease in oxygen isotope values has also been reported from the same region by Kent-Corson et al (2009). These results perfectly fit with the outcome of this study indicating that the long-term retreat of the proto-Paratethys Sea from Central Asia primarily occurred during the late Eocene.

\section{Conclusions}


The last and fifth marine incursion in the Tarim Basin was limited to its westernmost margin and occurred during the latest Bartonian-early Priabonian, showing that the sea had retreated westward before the EOT and isolation of the Paratethys Sea. Similar to the fourth transgression the palaeoenvironment of the fifth transgression was characterized by shallow marine conditions with well-established connections across Eurasia to the Western Tethys.

The apparent lack of diachronicity of the regressions from the southwest Tarim Basin and concomitant sea-level falls recorded in global marine records and Eurasian basins, corroborate that, in addition to long-term tectonic forcing of the stepwise westward retreat from Central Asia by early distal uplift of the Pamir-Kunlun orogenic system to the south, the individual regressions were forced by short-term eustatic sea-level lowering. Since both the fourth and fifth regressions coincide with significant aridification steps in the Xining Basin, the link between the middle to late Eocene records of the stepped proto-Paratethys Sea retreat from the Tarim Basin and the stepwise Asian aridification is now better established.

Later and farther long-term westward retreat of the sea from Central Asia, which eventually isolated as the Paratethys Sea, is still poorly constrained in time and space. The fifth and last regression studied here probably extended far westward into the neighbouring Ferghana and AfghanTajik Basins according to existing stratigraphic correlations (Burtman et al., 1996; Burtman, 2000). However, the sedimentary successions of these basins remain poorly dated such that further accurate litho-biostratigraphic study of their marine sediments is required to ascertain these correlations.

\section{Acknowledgements}

This project was funded by the Netherlands Organization for Scientific Research (NWO) with grants to Roderic Bosboom and Guillaume Dupont-Nivet and the Molengraaff Fund with a grant to Arjen Grothe. We acknowledge support from the Egide Cai Yuanpei program. We would like to thank Laurie Bougeois and Gloria Heilbronn for their contributions in the field, Tom Mullender and Mark Dekkers for their assistance in the palaeomagnetic laboratory, Franz Topka (NHM Vienna) for mollusc sample preparation and Natasja Welters for her assistance in the palynological laboratory. 


\section{Figure captions}

Fig. 1. Locations of the lithostratigraphic sections $(\mathrm{MI}=$ Bashibulake Mine; $\mathrm{KZ}=\mathrm{Kezi}$; $\mathrm{AT}=$ Aertashi; KY = Keliyang) are displayed on the schematic geological map of Central Asia displaying major tectonic features (modified from Cowgill, 2010). The inset shows the locations of the Tarim and Xining Basins on a large-scale map of Eurasia (present-day coastal outline obtained from GPlates 0.9.7.1).

Fig. 2. Simplified regional lithostratigraphic framework of the marine incursions recognized in the southwest Tarim Basin, compared temporally with the palaeogeographic evolution of the protoParatethys Sea, the regional tectonic evolution of the Pamir, Kunlun Shan and Tian Shan, the palaeoenvironmental changes recorded in the Asian interior and global climate events, based on the geological time scale (Gradstein et al., 2012). Also indicated is the disputable reoccurrence of minor brackish-marine incursions in the Miocene. See the discussion for references and a complete overview of the link between the proto-Paratethys Sea retreat and these different geological events, indicated by the thin-dotted lines. The formations, corresponding thicknesses and lithologies are summarized from Jia et al. (2004), Mao and Norris (1988) and Tang et al. (1989). Through our studies age estimates have been obtained for the Bashibulake Formation (this study), the Wulagen and the Kalatar Formations (Bosboom et al., 2011; Bosboom et al., in press), whereas for the older formations previous age estimates have been reviewed based upon calcareous nannofossils, bivalves, ostracods, dinoflagellate cysts and benthic foraminifera (Hao and Zeng, 1984; Mao and Norris, 1988; Zhong, 1992; Lan and Wei, 1995; Yang et al., 1995). The shaded area highlights the Bashibulake Formation corresponding to the fifth and last sea retreat from the westernmost margin of the Tarim Basin, which has been accurately dated by biostratigraphy in this study. The approximate relative changes in sea level of each transgression are shown by the thick-dotted line and are simply based upon the reported eastward extent of each incursion into the basin. . 
Fig. 3. Field photographs of formations and sedimentologic features at the Bashibulake Mine section. (a) Sinuous-crested ripples, trough cross-bedding and (b) incised channels in the fine sandstone beds of the first member of the Bashibulake Formation are indicative of a fluvial depositional environment. (c) Oysters in a red mudstone bed in the Bashibulake Formation. (d) Overview of the Bashibulake Mine section showing all the Paleogene formations recognized in the field. Note the alternation of red and green mudstones within the Bashibulake Formation.

Fig. 4. Lithostratigraphy and recognized age diagnostic biostratigraphic events correlated to the geological time scale (GTS12; Gradstein et al., 2012) for the southwest Tarim Basin. The biostratigraphic sample levels of this study are indicated next to the stratigraphic column. The same samples were analysed for foraminifera and ostracods. Zero level is defined by the uppermost greencoloured shell bed. Preliminary palaeo-waterdepth estimates are shown directly next to the lithostratigraphic columns, as well as the previously obtained magnetostratigraphic polarity pattern at the Aertashi and Kezi sections near the palaeodepocenter in the southwest Tarim Basin (Bosboom et al., in press). The biostratigraphic correlations are indicated by dotted lines and shaded areas (dark for calcareous nannofossils and light for dinoflagellate cysts). The last sea retreat in the western Tarim Basin is concomitant with a significant aridification step recognized in the Xining Basin at $\sim 37.1 \mathrm{Ma}$ (top of C17n.1n; named Step 1 by Abels et al., 2011) and short-term global cooling in the early Priabonian (C17n.1n; cooling event C by Villa et al., 2008 and Carbonate Accumulation Event 5 by Lyle et al., 2005).

Fig. 5a. The most important species of ostracods recognized. External lateral view of valves of ostracods, all belonging to adult individuals ( $\mathrm{LV}=$ left valve; $\mathrm{RV}=$ right valve). 1, 2. Cytherelloidea ex. gr. dameriacensis (Apostolescu); 1. carapace, view from RV; 2. LV. 3,4. Cytherella compressa (von Münster); 3. carapace, view from RV; 4. LV. 5,6. Cytherella sp., possible C. beyrichi with less visible ornamentation, carapaces, view from RV. 7,8. Paracypris sp.; 7. LV; 8. carapace, view from RV. 9,10. Pterigocyhtereis ceratoptera (Bosquet); 9. LV; 10. carapace, view from RV. 11,12. Loxoconcha ex. gr. nystiana Bosquet; 11. LV, female. 12. RV, male. 13, 14. Schuleridea ex. gr. 
perforata (Jones); 13. carapace, view from LV; 14. carapace, view from RV. 15, 16. Cytheridea eocaenica Pietrzeniuk; 15. LV; 16. carapace, view from RV. 17, 18. Cytheridea ex. gr. pernota Oertli and Key; 17. LV, male; 18. carapace, view from RV, female. 19, 20. Haplocytheridea ex. gr. curvata (Lienenklaus) 19. LV; 20. RV. 21. Cytheridea sandbergeri Kammerer, carapace, view from RV. 22, 23. Cytheromorpha aff. zinndorfi (Lienenklaus); 22. carapace, view from LV; 23, carapace, view from RV. 24. Grinioneis ex. gr. triebeli (Stchepinsky), carapace, view from LV. 25-28. Cytheretta ex. gr. eocaenica Keij; 25. carapace, view from LV, female; 26. carapace, view from RV, female; 27. carapace, view from LV, male; 28 . RV, male

Fig. 5b. The most important species of ostracods recognized (continued from Fig. 5a). External lateral view of valves of ostracods belong to adult individuals ( $L V=$ left valve; $R V=$ right valve). 1,2 . Cytheretta ex. gr. vulgaris Ducasse; 1. carapace, view from LV, female; 2, carapace, view from RV, male. 3, 4. Cytheretta (Flexus?) vulgaris Ducasse var "tricostulée"; 3. LV, male; 4. carapace, view from RV, male. 5, 6. Echinocythereis ? cf. hamsteadensis Keen; 5. LV. 6. carapace, view from RV. 7, 8. Eucytherura keiji Pietrzeniuk; 7. carapace, view from LV, female; 8. carapace, view from RV, female. 9, 10. "Leguminocythereis" sorneana Oertli; 9. LV. 10. RV. 11, 12. Rugieria semireticulata Haskins; 11. carapace, view from LV. 12. carapace, view from RV. 13. Paijenborchella tricostata (Lienenklaus), carapace view from RV and ventral.

Fig. 6. The species of molluscs identified. All specimens are in natural size. 1. Ostrea (Turkostrea) cizancourti Cox, 1939; left valve (-275.9 m level; MI-S02). 2. Ostrea (Turkostrea) cizancourti Cox, 1939; right valve (-275.9 m level; MI-S02). 3. Ostrea (Turkostrea) cizancourti Cox, 1939; left valve ($260.3 \mathrm{~m}$ level; MI-S03). 4. Ostrea (Turkostrea) cizancourti Cox, 1939; left valve (-250.7 m level; MIS04). 5. Kokanostrea kokanensis (Sokolow, 1910); left valve (-239.1 m level; MI-S07). 6. Ferganea bashibulakeensis Wei, 1984; left valve (-36.1 m level; MI-S11). 7. Ostrea (Turkostrea) cf. strictiplicata (Roulin and Delbos, 1855); strongly eroded left valve (-275.9 m level; MI-S02). 8. Platygena asiatica (Romanovskiy, 1879); fragment of the left valve (-58.9 m level; MI-S08). 9. Sokolowia buhsii (Grewingk, 1853); left valve (-239.1 m level; MI-S07). 10. Cubitostrea plicata 
(Solander, 1766); right valve (-51.2 m level; MI-S09). 11. Cubitostrea plicata (Solander, 1766); left valve (-51.2 m level; MI-S09). 12. Cubitostrea tianschanensis (Romanovskiy, 1884); right valve (-4.3 m level; MI-S13). 13. Flemingostrea kaschgarica (Vyalov, 1948); right valve (-242.5 m level; MIS05). 14. Flemingostrea kaschgarica (Vyalov, 1948); left valve (-242.5 m level; MI-S05). 15. Cubitostrea tianschanensis (Romanovskiy, 1884); left valve (-4.3 m, MI-S13). 16. Palliolum trigintaradiata (Sowerby, 1850); right valve (-239.1 m level; MI-S07). 17. Palliolum minblaki (Mirkamalova, 1958); right valve (-36.1 m level; MI-S11).

Fig. 7. The most important species of calcareous nannofossils recognized. Scale bar in each micrograph is $1 \mu .1,2$. Ericsonia formosa (MI-B26). 3, 4. Discoaster barbadiensis (MI-B05). 5. Lanternithus sp. side view, (MI-B05). 6. Zigrablithus bijugatus (MI-B05). 7. Lanternithus arcanus (MI-B05). 8-10. Cribrocentrum reticulatum (8: MI-B39; 9, 10: MI-B26). 11, 12. Blackites sp. (MIB05; 11: x nicols; 12: phase contrast). 13. Reticulofenestra umbilicus (MI-B26). 14. Transversopontis pulcheroides (MI-B05). 15. Neococcolithes dubius (MI-B05). 16. Blackites spinosus (MI-B23).

Fig. 8. Important dinoflagellate cysts and green algae. Scale bar in each micrograph is $20 \mathrm{~m} \mu$ (apart from micrograph 5 which is only $5 \mathrm{~m} \mu$ as indicated). Adnatosphaeridium multispinosum (MI-B16). 2. Areosphaeridium diktyoplokum (MI-B5). 3. Charlesdowniea coleothrypta subsp. rotundata (MI-B39). 4. Charlesdowniea coleothrypta (MI-B39). 5. Same specimen as plate 4 showing close up of membranous ectophragm (MI-B39). 6. Charlesdowniea tenuivirgula/crassiramosa (MI-B5). 7. Charlesdowniea crassiramosa (MI-B5). 8. Cordosphaeridium funiculatum (MI-B16). 9. Enneadocysta pectiniformis (MI-B16). 10. Hystrichokolpoma rigaudiae (MI-B5). 11. Hystrichosphaeridium salpingophorum (MI-B5). 12. Lentinia serrata (MI-B16). 13. Rhombodinium draco (MI-B16). 14. Wetzeliella cf. gochtii (MI-B16). 15. Tasmanites spp. (MI-B16).

Fig. 9. Geographic map displaying the present-day extent and age of the marine sediments associated to the fourth and last fifth incursions, based upon data of this study, Bosboom et al. (2011; in press) and a review of the distribution of existing reports of marine sediments throughout the Tarim Basin 
(e.g. Tang et al., 1989; Lan and Wei, 1995). The digital elevation data was downloaded from the

online database of the CGIAR Consortium for Spatial Information (Jarvis et al., 2008).

\section{References}

Abels, H.A., Dupont-Nivet, G., Xiao, G., Bosboom, R.E., Krijgsman, W., 2011. Step-wise Asian paleoenvironmental changes preceding the Eocene - Oligocene Transition (EOT) in the terrestrial Xining Basin, China. Palaeogeography, Palaeoclimatology, Palaeoecology 299, 399-412.

Aigner, T., Brandenburg, A., van Vliet, A., Lawrence, D., Westrich, J., 1990. Stratigraphic modelling of epicontinental basins: two applications. Sedimentary Geology 69, 167-190.

Akhmetiev, M.A., 2007. Paleocene and Eocene floras of Russia and adjacent regions: Climatic conditions of their development. Paleontological Journal 41, 1032-1039.

Akhmetiev, M.A., Beniamovski, V.N., 2006. The Paleocene and Eocene in the Russian part of west Eurasia. Stratigraphy and Geological Correlation 14, 49-72.

Allen, M.B., Armstrong, H.A., 2008. Arabia-Eurasia collision and the forcing of mid-Cenozoic global cooling. Palaeogeography, Palaeoclimatology, Palaeoecology 265, 52-58.

Amidon, W.H., Hynek, S.A., 2010. Exhumational history of the north central Pamir. Tectonics 29, TC5017.

Apostolescu, V., 1955. Description de quelques Ostracodes du Lutétiene du Bassin de Paris, Cahiers Géologiques de Thoiry, pp. 241-279.

Apostolescu, V., 1962. Répartition stratigraphique générale des Ostracodes du Paléogene des Bassins de Paris et de Bruxelle. Mém. Bur. Rech. Geol. min. 28, 1035-1040.

Apostolescu, V., Dellenbach, J., 1999. Les ostracodes oligocenes de Haute-Provence. Une contribution a la Palaeobiogeographie de l'Oligocene.

Báldi, T., 1984. The terminal Eocene and Early Oligocene events in Hungary and the separation of an anoxic, cold Paratethys. Eclogae Geologocae Helvetiae 77, 1-27.

Berizzi Quarto di Palo, A., 1970. Paleogene Pelecypods from Kataghan and Badakhshan (North-East Afganistan), in: Desio, A. (Ed.), Fossils of North-East Afganistan: Italian Expeditions to the Karakorum (K2), and Hindu Kush, IV/2:. Brill, Leiden, pp. 161-240.

Bershaw, J., Garzione, C.N., Schoenbohm, L., Gehrels, G., Tao, L., 2012. Cenozoic evolution of the Pamir plateau based on stratigraphy, zircon provenance, and stable isotopes of foreland basin sediments at Oytag (Wuyitake) in the Tarim Basin (west China). Journal of Asian Earth Sciences 44, 136-148.

Bonaduce, G., Ciampo, G., Masoli, M., 1975. Distribution of Ostracoda in the Adriatic Sea. Stazione zoologica di Napoli.

Bosboom, R.E., Abels, H.A., Hoorn, C., van den Berg, B.C.J., Guo, Z., Dupont-Nivet, G., 2014. Descent into icehouse-climate state on the Asian continent after the Middle Eocene Climatic Optimum (MECO). Earth and Planetary Science Letters 389, 34-42.

Bosboom, R.E., Dupont-Nivet, G., Grothe, A., Brinkhuis, H., Villa, G., Mandic, O., Stoica, M., Huang, W., Yang, W., Guo, Z., Krijgsman, W., in press. Linking Tarim Basin sea retreat (west China) and Asian aridification in the late Eocene. Basin Research.

Bosboom, R.E., Dupont-Nivet, G., Houben, A.J.P., Brinkhuis, H., Villa, G., Mandic, O., Stoica, M., Zachariasse, W.-J., Guo, Z., Li, C., 2011. Late Eocene sea retreat from the Tarim Basin (West China) and concomitant Asian paleoenvironmental change. Palaeogeography, Palaeoclimatology, Palaeoecology 299, 385-398.

Bown, P., 2005. Selective calcareous nannoplankton survivorship at the Cretaceous-Tertiary boundary. Geology 33, 653-656.

Bown, P.R., Young, J.R., 1998. Introduction, in: Bown, P.R. (Ed.), Calcareous Nannofossil Biostratigraphy: British Micropalaeontology Society Series. Chapman and Hall, London, pp. 1-15.

Brinkhuis, H., 1994. Late Eocene to Early Oligocene dinoflagellate cysts from the Priabonian type-area (Northeast Italy): biostratigraphy and paleoenvironmental interpretation. Palaeogeography, Palaeoclimatology, Palaeoecology 107, 121-163.

Browning, J.V., Miller, K.G., Pak, D.K., 1996. Global implications of lower to middle Eocene sequence boundaries on the New Jersey coastal plain: The icehouse cometh. Geology 24, 639-642. 
Budd, D.A., Harris, P.M., 1990. Carbonate-Siliciclastic mixtures, SEPM Reprint series number 14. SEPM, Tulsa, Oklahoma, p. 272.

Burtman, V.S., 2000. Cenozoic crustal shortening between the Pamir and Tien Shan and a reconstruction of the Pamir-Tien Shan transition zone for the Cretaceous and Palaeogene. Tectonophysics 319, 69-92.

Burtman, V.S., Molnar, P., 1993. Geological and geophysical evidence for deep subduction of continental crust beneath the Pamir. Geological Society of America Special Paper 281, 1-76.

Burtman, V.S., Skobelev, S.F., Molnar, P., 1996. Late Cenozoic slip on the Talas-Ferghana fault, the Tien Shan, central Asia. Geological Society of America Bulletin 108, 1004-1021.

Carbonnel, G., 1998. Les niveaux à Pterigocythereis dans le Miocène rhodanien: épisode hydrodinamique privilégié. . Géologie Méditerannée 25, 19-31.

Clark, M.K., Farley, K.A., Zheng, D., Wang, Z., Duvall, A.R., 2010. Early Cenozoic faulting of the northern Tibetan Plateau margin from apatite (U-Th)/He ages. Earth and Planetary Science Letters 296, 78-88.

Costa, E., Garcés, M., López Blanco, M., Beamud, E., Gómez-Paccard, M., Larrasoaña, J.C., 2010. Closing and continentalization of the South Pyrenean foreland basin (NE Spain): magnetochronological constraints. Basin Research 22, 904-917.

Coutand, I., Strecker, M.R., Arrowsmith, R., Hilley, G., Thiede, R.C., Korjenkov, A., Omuraliev, M., 2002. Late Cenozoic tectonic development of the intramontane Alai Valley, (Pamir-Tien Shan region, central

Asia): An example of intracontinental deformation due to the Indo-Eurasia collision. Tectonics 21, 3-13-19.

Cowgill, E., 2010. Cenozoic right-slip faulting along the eastern margin of the Pamir salient, northwestern China. Geological Society of America Bulletin 122, 145-161.

Dai, J., Wang, C., Hourigan, J., Santosh, M., 2013. Insights into the early Tibetan Plateau from (Uâ€"Th)/He thermochronology. Journal of the Geological Society 170, 917-927.

Dawber, C.F., Tripati, A.K., Gale, A.S., MacNiocaill, C., Hesselbo, S.P., 2011. Glacioeustasy during the middle Eocene? Insights from the stratigraphy of the Hampshire Basin, UK. Palaeogeography, Palaeoclimatology, Palaeoecology 300, 84-100.

De Grave, J., Glorie, S., Ryabinin, A., Zhimulev, F., Buslov, M.M., Izmer, A., Elburg, M., Vanhaecke, F., 2012. Late Palaeozoic and Meso-Cenozoic tectonic evolution of the Southern Kyrgyz Tien Shan: constraints from multi-method thermochronology in the Trans-Alai, Turkestan-Alai Section and the Southeastern Ferghana Basin. Journal of Asian Earth Sciences 44, 149-168.

DeConto, R.M., Pollard, D., 2003. Rapid Cenozoic glaciation of Antarctica induced by declining atmospheric CO2. Nature 421, 245-249.

Dercourt, J., Ricou, L.E., Vrielynck, B., 1993. Atlas Tethys paleoenvironmental maps. Commision for the Geological Map of the World, Paris, p. 269.

Ducasse, O., 1969. Etude micropaléontologique (Ostracodes) de l'Eocene nord-aquitain. Interprétation biostratigraphique et paléogéographique. Thèse Bordeaux.

Ducasse, O., Guernet, C., Ambareau, Y., 1985a. Paléogène, in: Oertli, H.J. (Ed.), Atlas des Ostracodes de France. Bulletin Centres Recherche Exploration-Production Elf-Aquitaine, pp. 257-311.

Ducasse, O., Lété, C., Roussele, L., 1985b. Contribution à l'étude paléontologique d'une crise Paléogène; population d'ostracodes à la limite Eocène - Oligocène dans le Medoc (Gironde). Bulletin de l'Institut de Géologie du Bassin d'Aquitaine 38, 141-175.

Dupont-Nivet, G., Hoorn, C., Konert, M., 2008. Tibetan uplift prior to the Eocene-Oligocene climate transition: evidence from pollen analysis of the Xining Basin. Geology 36, 987-990.

Dupont-Nivet, G., Krijgsman, W., Langereis, C.G., Abels, H.A., Dai, S., Fang, X., 2007. Tibetan plateau aridification linked to global cooling at the Eocene-Oligocene transition. Nature 445, 635-638.

Esteban-Delgado, F.J., Harper, E.M., Checa, A.G., Rodríguez-Navarro, A.B., 2008. Origin and expansion of foliated microstructure in pteriomorph bivalves. Biological Bulletin 214, 153-165.

Fensome, R.A., Williams, G.L., 2004. The Lentin and Williams index of fossil dinoflagellates. American Association of Stratigraphic Palynologists Foundation Contributions Series, Salt Lake City, Utah.

Fornaciari, E., Agnini, C., Catanzariti, R., Rio, D., Bolla, E.M., Valvasoni, E., 2010. Mid-latitude calcareous nannofossil biostratigraphy and biochronology across the middle to late Eocene transition. Stratigraphy 7, 229

Gao, Z., Chen, K., Wei, J., 2000. The Lithostratigraphic Dictionary of China. China University of Geosciences Press, Beijing.

Gasson, E., Siddall, M., Lunt, D.J., Rackham, O.J.L., Lear, C.H., Pollard, D., 2012. Exploring uncertainties in the relationship between temperature, ice volume, and sea level over the past 50 million years. Reviews of Geophysics 50, 1-35.

Gomes-Rodrigues, H., Marivaux, L., Vianey-Liaud, M., 2012. Expansion of open landscapes in Northern China during the Oligocene induced by dramatic climate changes: Paleoecological evidence. Palaeogeography, Palaeoclimatology, Palaeoecology 358-360, 62-71. 
Gradstein, F.M., Ogg, J.G., Schmitz, M., Ogg, G., 2012. The Geologic Time Scale 2012. Cambridge University Press, Cambridge.

Graham, S.A., Chamberlain, C.P., Yue, Y.J., Ritts, B.D., Hanson, A.D., Horton, T.W., Waldbauer, J.R., Poage, M.A., Feng, X., 2005. Stable isotope records of Cenozoic climate and topography, Tibetan plateau and Tarim basin. American Journal of Science 305, 101-118.

Grewingk, C., 1853. Die geognostischen und orographischen Verhaeltnisse des noerdlichen Persiens. Verhandlungen der R.K Mineralogischen Gesellschaft 1852-1853, 97-245.

Guo, X., 1991. An approach to the depositional environment of the Cretaceous Kizilsu Group: The lowermost marine horizon of the Cretaceous in the western Tarim Basin. Acta Geological Sinica 2, 188-198.

Hao, Y.C., Zeng, X.L., 1984. On the evolution of the west Tarim gulf from Mesozoic to Cenozoic in terms of characteristics of foraminiferal fauna. Acta Micropalaeontologica Sinica 1, 1-13.

Haskins, C.W., 1967. Tertiary Ostracoda from the Isle of Wight and Barton, Hampshire, England. Part I. Revue de Micropaléontolgie 10, 250-260.

He, C., 1991. Late Cretaceous-Early Tertiary Microphytoplankton from the Western Tarim Basin in Southern Xinjiang, China. Science Press, Beijing.

Heilmann-Clausen, C., Van Simaeys, S., 2005. Dinoflagellate cysts from the middle Eocene to ?lowermost Oligocene succession in the Kysing research borehole, Central Danish Basin. Palynology 29, 143-204.

Hendrix, M.S., Graham, S.A., Carroll, A.R., Sobel, E.R., Mcknight, C.L., Schulein, B.J., Wang, Z., 1992. Sedimentary record and climatic implications of recurrent deformation in the Tian Shan: Evidence from Mesozoic strata of the north Tarim, south Junggar, and Turpan basins, northwest China. Geological Society of America Bulletin 104, 53-79.

Hoorn, C., Straathof, J., Abels, H.A., Yadong, X., Utescher, T., Dupont-Nivet, G., 2012. Late Eocene palynological record of climate change and Tibetan Plateau uplift (Xining Basin, China). Palaeogeography, Palaeoclimatology, Palaeoecology 344-345, 16-38.

Houben, A.J.P., Bijl, P.K., Guerstein, G.R., Sluijs, A., Brinkhuis, H., 2011. Malvinia escutiana, a new biostratigraphically important Oligocene dinoflagellate cyst from the Southern Ocean. Review of Palaeobotany and Palynology 165, 175-182.

Hu, B., 1992. Petroleum Geology and Prospects of the Tarim (Talimu) Basin, China, in: Halbouty, M.T. (Ed.), Giant Oil and Gas Fields of the Decade 1978-1988. American Association of Petroleum Geologists, Tulsa, pp. 493-510.

Hu, Y., 1982. Late Tertiary foraminifer ecology of the Tarim basin and its geological significance. Chinese Science Bulletin 27, 938-941.

Iakovleva, A.I., Heilmann-Clausen, C., 2010. Eocene Dinoflagellate Cyst Biostratigraphy of Research Borehole 011-BP, Omsk Region, Southwestern Siberia. Palynology 34, 195-232.

Jarvis, A., Reuter, H.I., Nelson, A., Guevara, E., 2008. Hole-filled seamless SRTM data V4. International Centre for Tropical Agriculture (CIAT), available from http://srtm.csi.cgiar.org.

Jia, C., Wei, G., Wang, L., Jia, D., Guo, Z., 1997. Tectonic characteristics and petroleum, Tarim basin, China. Petroleum Industry Press, Beijing, p. 295.

Jia, C., Zhang, S., Wu, S., 2004. Stratigraphy of the Tarim Basin and Adjacent Areas. Science Press, Beijing.

Johnson, C.L., Hudson, S.M., Rowe, H.D., Efendiyeva, M.A., 2009. Geochemical constraints on the PalaeoceneMiocene evolution of eastern Azerbaijan, with implications for the South Caspian basin and eastern Paratethys. Basin Research 22, 733-750.

Jolivet, M., Brunel, M., Seward, D., Xu, Z., Yang, J., Roger, F., Tapponnier, P., Malavieille, J., Arnaud, N., Wu, C., 2001. Mesozoic and Cenozoic tectonics of the northern edge of the Tibetan Plateau: Fission-track constraints. Tectonophysics 343, 111-134.

Kammerer, T., 1993. Ostracoden aus dem Oberem Rupelton, Schleichsand und Cyrenmergel (Zwischenschichten, Rupelium bis unteres Chattium) des Mainzer Beckens, Mainz.

Katz, M.E., Miller, K.G., Wright, J.D., Wade, B.S., Browning, J.V., Cramer, B.S., Rosenthal, Y., 2008. Stepwise transition from the Eocene greenhouse to the Oligocene icehouse. Nature Geoscience 1, 329-334.

Keen, M.C., 1978. The Tertiary- Paleogene, in: Bate, R.H., Robinson, E. (Eds.), A stratigraphical index of British Ostracoda. Seel House Press, Liverpool, pp. 385-449.

Keen, M.C., 1989. Oligocene ostracod biofacies from onshore areas of the North Sea Basin, in: Batten, D.J., Keen, M.C. (Eds.), Northwest European micropalaeontology and palynology. Ellis Horwood Limited, Chichester, pp. 248-264.

Keij, A.J., 1957. Eocene and Oligocene Ostracoda of Belgium. Mémoires Institut Royal des Sciences Naturelles de Belgique, Brussels.

Kent-Corson, M.L., Ritts, B.D., Zhuang, G., Bovet, P.M., Graham, S.A., Page Chamberlain, C., 2009. Stable isotopic constraints on the tectonic, topographic, and climatic evolution of the northern margin of the Tibetan Plateau. Earth and Planetary Science Letters 282, 158-166. 
Kominz, M.A., Browning, J.V., Miller, K.G., Sugarman, P.J., Mizintseva, S., Scotese, C.R., 2008. Late Cretaceous to Miocene sea-level estimates from the New Jersey and Delaware coastal plain coreholes: An error analysis. Basin Research 20, 211-226.

Kraatz, B.P., Geisler, J.H., 2010. Eocene-Oligocene transition in Central Asia and its effects on mammalian evolution. Geology 38, 111-114.

Lan, X., 1997. Paleogene bivalve communities in the western Tarim Basin and their paleoenvironmental implications. Paleoworld 7, 137-157.

Lan, X., Wei, J., 1995. Late Cretaceous-Early Tertiary Marine Bivalve Fauna From the Western Tarim Basin. Chinese Science Publishing House, Beijing, p. 212.

Lartaud, F., 2007. Les fluctuation haute fréquence de l'environnement au cours des temps géologiques. Mise au point d'un modèle de réféference actuel sur l'enrigestrement des contrastes saisonniers dans l'Atlantique nord., Sciences de la Terre. Université de Pierre et Marie Curie, Paris, p. 337.

Lear, C.H., Bailey, T.R., Pearson, P.N., Coxall, H.K., Rosenthal, Y., 2008. Cooling and ice growth across the Eocene-Oligocene transition. Geology 36, 251-254.

Libeau, A., 1980. Palä obathymetrie und Ö kofactoren: Flachmeer-Zonierungen, Neues Jahrbuch für Geologie und Paläontologie Abhandlungen, Stuttgart, pp. 173-216.

López-Blanco, M., Marzo, M., Burbank, D.W., Vergés, J., Roca, E., Anadón, P., Piña, J., 2000. Tectonic and climatic controls on the development of foreland fan deltas: Montserrat and Sant Llorenç del Munt systems (Middle Eocene, Ebro Basin, NE Spain). Sedimentary Geology 138, 17-39.

Lord, A.R., Whittacker, J.E., King, C., 2009. Paleogene, in: Whitaker, J.E., Hart, M.B. (Eds.), Ostracods in British Stratigraphy. The Micropaleontological Society, Special Publications, London, pp. 374-409.

Lyle, M., Olivarez-Lyle, A., Backman, J., Tripati, A., 2005. Biogenic sedimentation in the Eocene equatorial Pacific - the stuttering greenhouse and Eocene carbonate compensation depth, in: Wilson, P.A., Lyle, M., Firth, J.V. (Eds.), Proceedings of the Ocean Drilling Program, Scientific Results, pp. 1-35.

Malz, H., 1962. Tertiä r des Rheintalgrabens: B10b Taxonomie: Ostracoda. , Arbeitskreis deutscher Mikropalä ontologen: Leitfossilien der Mikropalä ontologie. Gebrüder Bornträ ger, Berlin, pp. 391 398.

Mandelstam, M.I., 1958. New ostracode genera and species. Trudy VNIGRI (new series) 115, 232-299.

Mao, S., Norris, G., 1988. Late Cretaceous-early Tertiary dinoflagellates and acritarchs from the Kashi area, Tarim Basin, Xinjiang Province, China. Royal Ontario Museum, Toronto.

Martini, E., 1970. Standard Tertiary and Quaternary calcareous nannoplankton zonation, in: Farinacci, A. (Ed.), Proceedings 2nd International Conference Planktonic Microfossils, Roma, pp. 739-785.

Meng, Z., Deng, Y., Ding, Z., Li, Y., Sun, D., 1998. New paleomagnetic results from Ceno-Mesozoic volcanic rocks along southern rim of the Tarim Basin, China. Sciene in China Series D Earth Sciences (English edition) 41, 91-104.

Miller, K.G., Kominz, M.A., Browning, J.V., Wright, J.D., Mountain, G.S., Katz, M.E., Sugarman, P.J., Cramer, B.S., Christie-Blick, N., Pekar, S.F., 2005. The Phanerozoic Record of Global Sea-Level Change. Science 310, 1293-1298.

Monostori, M., 2004. Lower Oligocene (Kiscellian) ostracods in Hungary-Systematic description, Universitatis Scientiarum Budapestinensis, Sectio Geologica, Budapest, pp. 27-141.

Murray, J.W., Curry, D., Haynes, J.R., King, C., 1989. Paleogene, in: Jenkyns, D.G., Murray, J.W. (Eds.), Stratigraphical atlas of fossil foraminifera. Ellis Horwood, Chichester, p. 536.

Muzylev, N.G., Rasulov, U.M., Khokhlova, I.E., Kushakov, A.R., 1996. The Upper Eocene of the Fergana Depression and Adjacent Regions: Stratigraphy and Geological Correlation. 4, 141-147.

Neal, J.E., Hardenbol, J., 1998. Introduction to the Palaeogene, in: De Graciansky, P.C., Hardenbol, J., Jaquin, T. (Eds.), Mesozoic and Cenozoic sequence stratigraphy of European basins, SEPM Special Publication, pp. 87-90.

Nocchi, M., Parisi, G., Monaco, P., Monechi, S., Madile, M., Napoleone, G., Ripepe, M., Orlando, M., Premoli Silva, I., Bice, D.M., 1986. The Eocene-Oligocene boundary in the Umbrian pelagic sequences, Italy., in: Pomerol, C., Premoli Silva, I. (Eds.), Terminal Eocene Events: Developments in Palaeontology and Stratigraphy, pp. 24-40.

Oertli, H.J., 1956. Ostracoden aus der oligozänen und miocänen Molasse der Schweiz. Schweizerische Paläontologische Abhandlungen 74, 1-119.

Oertli, H.J., Key, A.J., 1955. Drei neue Ostrakoden Arten aus dem Oligozä n Westeuropas. Bulletin der Vereinigung Schweizerischer Petroleum-Geologen und -Ingenieure 22, 19-28.

Okada, H., Bukry, D., 1980. Supplementary modification and introduction of code numbers to the low latitude coccolith biostratigraphic zonation (Bukry 1973, 1975). Marine Micropaleontology 5, 321-325.

Olteanu, R., 2006. Monografia ostracodelor tertiare din arealul carpatic. Editura Academei Romane, Bucuresti.

Olteanu, R., Popescu, B., 1973. Considerații paleontologice şi sedimentologice privind evoluţia ostracodelor in Eocenul de la vest de Cluj. St., Cerc., Geol., Geofiz., Geogr., Seria Geologie 18, 245-260. 
Pekar, S.F., Christie-Blick, N., Kominz, M.A., Miller, K.G., 2002. Calibration between eustatic estimates from backstripping and oxygen isotopic records for the Oligocene. Geology 30, 903.

Picot, L., 2002. Le Paléogène des synclinaux du Jura et de la bordure sud-rhénane: paléontologie (Ostracodes), paléoécologie, biostratgraphie et paléogéographie. Geofocus, Fribourg.

Picot, L., Besker, D., Cavin, L., Pirkenseer, C., Lapaire, F., Rauber, G., Hochuli, P.A., Spezzaferri, S., Berger, J.P., 2008. Sédimentologie et paléontologie (foraminifères, ostracodes, poissons) des paléoenvironnements côtiers rupéliens de la Mollasse marine rhénane dans le Jura suisse. Swiss Journal of Geosciences 101, 483-513.

Pietrzeniuk, E., 1969. Taxonomische und biostratigraphishe Untersuchungen an Ostracoden des Eozän 5 im Norden der Deutschen Demokratischen Republik. Paläontologische Abhandlungen Abteilung A: Paläozoologie, Berlin.

Pirkenseer, C., Berger, J.P., 2011. Paleogene Ostracoda from the southern Upper Rhine Graben: Taxonomy, palaeogeoecology and palaeobiogeography. Palaeontographica, Abteilung A 295, 1-149.

Popov, S., Rögl, F., Rozanov, A.Y., Steininger, F.F., Shcherba, I.G., Kovac, M., 2004. LithologicalPaleogeographic maps of Paratethys 10 Maps Late Eocene to Pliocene. Courier Forschungsinstitut Senckenberg 250, 1-42.

Popov, S.V., Sychevskaya, E.K., Akhmetiev, M.A., Zaporozhets, N.I., Golovina, L.A., 2008. Stratigraphy of the Maikop Group and Pteropoda Beds in northern Azerbaijan. Stratigraphy and Geological Correlation 16 , 664-677.

Powell, A.J., Brinkhuis, H., Bujak, J.P., 1996. Upper Paleocene-Lower Eocene dinoflagellate cyst sequence biostratigraphy of southeast England. Geological Society Special Publications 101, 145-183.

Pross, J., Brinkhuis, H., 2005. Organic-walled dinoflagellate cysts as paleoenvironmental indicators in the Paleogene; a synopsis of concepts. Paläontologische Zeitschrift 79, 53-59.

Proust, J.N., Hosu, A., 1996. Sequence stratigraphy and Paleogene tectonic evolution of the Transylvanian Basin (Romania, eastern Europe). Sedimentary Geology 105, 117-140.

Quan, C., Liu, Y.-S.C., Utescher, T., 2012. Paleogene temperature gradient, seasonal variation and climate evolution of northeast China. Palaeogeography. Palaeoclimatololgy. Palaeoecololgy 313-314, 150-161.

Quan, C., Liu, Y.S.C., Utescher, T., 2011. Paleogene evolution of precipitation in northeastern China supporting the middle Eocene intensification of the East Asian monsoon. PALAIOS 26, 743-753.

Ramstein, G., Fluteau, F., Besse, J., Joussaume, S., 1997. Effect of orogeny, plate motion and land-sea distribution on Eurasian climate change over the past 30 million years. Nature 386, 788-795.

Reading, H.G., 2006. Sedimentary Environments: Processes, Facies and Stratigraphy. Blackwell Publishing Inc., Oxford, p. 688.

Ritts, B.D., Yue, Y., Graham, S.A., Sobel, E.R., Abbink, O.A., Stockli, D., 2008. From sea level to high elevation in 15 million years:Uplift history of the northern Tibetan Plateau margin in the Altun Shan. American Journal of Science 308, 657-678.

Robinson, A.G., Rudat, J.H., Banks, C.J., Wiles, R.L.F., 1996. Petroleum geology of the Black Sea. Marine and Petroleum Geology 13, 195-223.

Robinson, D.M., Dupont-Nivet, G., Gehrels, G.E., Zhang, Y., 2003. The Tula Uplift, northwestern China; evidence for regional tectonism of the northern Tibetan Plateau during late Mesozoic-early Cenozoic time. Geological Society of America Bulletin 115, 35-47.

Rögl, F., 1999. Short note: Mediterranean and Paratethys. Facts and Hypotheses of an Oligocene to Miocene Paleogeography (Short Overview). Geologica Carpathica 50, 339-349.

Rowley, D.B., Currie, B.S., 2006. Palaeo-altimetry of the late Eocene to Miocene Lunpola basin, central Tibet. Nature 439, 677-681 doi:610.1038/nature04506.

Rusu, A., 1985. Oligocene events in Transylvania (Roumania) and the first separation of Paratethys. Dari de Seama ale Sedintelor Institutul de Geologie si Geofizica 72-73, 207-223.

Rusu, A., Brotea, D., Melinte, M.C., 2004. Biostratigraphy of the Bartonian deposits from Gilău area (NW Transylvania, Romania). Acta Palaeontologica Romaniae 4, 441-454.

Schulz, H.-M., Bechtel, A., Sachsenhofer, R.F., 2005. The birth of the Paratethys during the Early Oligocene: From Tethys to an ancient Black Sea analogue? Global and Planetary Change 49, 163-176.

Sobel, E.R., Chen, J., Heermance, R.V., 2006. Late Oligocene-Early Miocene initiation of shortening in the Southwestern Chinese Tian Shan: Implications for Neogene shortening rate variations. Earth and Planetary Science Letters 247, 70-81.

Sobel, E.R., Dumitru, T.A., 1997. Thrusting and exhumation around the margins of the western Tarim basin during the India-Asia collision. Journal of Geophysical Research 102, 5043-5063.

Sönmez-Gökçen, N., 1973. Etude paléontologique (Ostracodes) et startigraphique des niveaux de Paléogène du Sud-Est de la Thrace Sciences Naturelles, Paris.

Sun, J., Jiang, M., 2012. Eocene seawater retreat from the southwest Tarim Basin and implications for early Cenozoic tectonic evolution in the Pamir Plateau. Tectonophysics 588, 27-38. 
Szczechura, J., 1977. Ostracods from the Upper Eocene of East Poland. Acta Palaeontologica Polonica 22, 55 92.

Tang, T., Xue, Y., Yu, C., 1992. Characteristics and sedimentary environments of the Late Cretaceous to early Tertiary marine strata in the western Tarim, China. Science Press, Beijing.

Tang, T., Yang, H., Lan, X., Yu, C., Xue, Y., Zhang, Y., Hu, L., Zhong, S., Wei, J., 1989. Marine Late Cretaceous and Early Tertiary Stratigraphy and Petroleum geology in Western Tarim Basin, China. Science Press, Beijing.

Thomas, J.-C., Chauvin, A., Gapais, D., Bazhenov, M.L., Perroud, H., Cobbold, P.R., Burtman, V.S., 1994. Paleomagnetic evidence for Cenozoic block rotations in the Tadjik depression (Central Asia). Journal of Geophysical Research 99, 15141-15160.

Tian, Z., Chai, G., Kang, Y., 1989. Tectonic evolution of the Tarim basin, in: Zhu, X. (Ed.), Chinese Sedimentary Basins. Elsevier, Amsterdam, pp. 33-42.

Uffenorde, H., 1986. Stratigraphical and palaeoecological aspects of Upper Oligocene Ostracoda of Lower Saxony, Nordwestdeutchalnd im Tertiä r, Teil 1. Beiträge zur Regionalen Geologie der Erde, pp. 422436.

Vail, P.R., Mitchum Jr, R.M., 1979. Global Cycles of Relative Changes of Sea Level from Seismic Stratigraphy: Resources, Comparative Structure, and Eustatic Changes in Sea Level.

van Hinsbergen, D.J.J., Lippert, P.C., Dupont-Nivet, G., McQuarrie, N., Doubrovine, P.V., Spakman, W., Torsvik, T.H., 2012. Greater India Basin hypothesis and a two-stage Cenozoic collision between India and Asia. Proceedings of the National Academy of Sciences 109, 7659-7664.

Van Wagoner, J.C., Posamentier, H.W., Mitchum, R.M., Vail, P.R., Sarg, J.F., Loutit, T.S., Hardenbol, J., 1988. An overview of the fundementals of sequence stratigraphy and key definitions, Sea-level Changes--An Integrated Approach. - Society of Economic Paleotologists and Mineralologists Special Publication.

Vialov, O.S., 1937. Sur la clasification des ostreides et leur valeur stratigraphique, Intern. Congr. Zool., Lisbonne, pp. 1627-1638.

Villa, G., Fioroni, F., Pea, L., Bohaty, S., Persico, D., 2008. Middle Eocene-late Oligocene climate variability: Calcareous nannofossil response at Kerguelen Plateau, Site 748. Marine Micropaleontology 69, 173192.

Vincent, S.J., Allen, M.B., Ismail-Zadeh, A.D., Flecker, R., Foland, K.A., Simmons, M.D., 2005. Insights from the Talysh of Azerbaijan into the Paleogene evolution of the South Caspian region. GSA Bulletin 117, 1513-1533.

Wade, B.S., Pearson, P.N., 2008. Planktonic foraminiferal turnover, diversity fluctuations and geochemical signals across the Eocene/Oligocene boundary in Tanzania. Marine Micropaleontology 68, 244-255.

Wang, C., Hong, H., Li, Z., Yin, K., Xie, J., Liang, G., Song, B., Song, E., Zhang, K., 2012. The EoceneOligocene climate transition in the Tarim Basin, Northwest China: Evidence from clay mineralogy. Applied Clay Science 74, 10-19.

Wang, C., Zhao, X., Liu, Z., Lippert, P.C., Graham, S.A., Coe, R.S., Yi, H., Zhu, L., Liu, S., Li, Y., 2008. Constraints on the early uplift history of the Tibetan Plateau. Proceedings of the National Academy of Sciences 105, 4987-4992.

Wei, H.-H., Meng, Q.-R., Ding, L., Li, Z.-Y., 2013. Tertiary evolution of the western Tarim basin, northwest China: a tectono-sedimentary response to northward indentation of the Pamir salient. Tectonics.

Wood, S.V., 1861. A monograph of the Eocene Mollusca or descriptions of shells from the older Tertiaries of England. Part 1. Bivalves. Palæontographical Society, London.

Yang, H., Jiang, X., Lin, S., 1995. Late Cretaceous- early Tertiary ostracod fauna from western Tarim Basin, south Xinjiang, China. Science Press, Beijing.

Yang, H.J., Shen, J.W., Zhang, L.J., Li, M., Huang, Z.B., Wang, Y., 2012. Serpulids and their paleoecology of the Paleogene Kalatar Formation in southwest Tarim Basin of China. Science China Earth Sciences 55, 1087-1100.

Yang, W., Jolivet, M., Dupont-Nivet, G., Guo, Z., in press. Mesozoic-Cenozoic tectonic evolution of southwestern Tian Shan: Evidence from detrital zircon $\mathrm{U} / \mathrm{Pb}$ and apatite fission track ages of the Ulugqat area, Northwest China. Gondwana Research.

Yang, Y., Liu, M., 2002. Cenozoic deformation of the Tarim plate and the implications for mountain building in the Tibetan plateau and the Tian Shan. Tectonics 21, 1059.

Ye, D., Zhong, X., Yao, Y., Yang, F., Zhang, S., Jiang, Z., Wang, Y., Sun, Z., Yang, S., Zhao, X., Shen, H., Liang, H., Tang, W., Guan, X., Zhao, C., 1996. Tertiary in petroliferous regions of China. Petroleum Industry Press, Beijing.

Yin, A., Harrison, M.T., 2000. Geologic evolution of the Himalayan-Tibetan orogen. Annual Review of Earth and Planetary Sciences 28, 211-280.

Yin, A., Rumelhart, P.E., Butler, R.F., Cowgill, E., Harrison, T.M., Foster, D.A., Ingersoll, R.V., Zang, Q., Zhou, X.-Q., Wang, X.-F., Hanson, A., Raza, A., 2002. Tectonic history of the Altyn Tagh fault system 
in northern Tibet inferred from Cenozoic sedimentation. Geological Society of America Bulletin 114, $1257-1295$

Zachos, J.C., Dickens, G.R., Zeebe, R.E., 2008. An early Cenozoic perspective on greenhouse warming and carbon-cycle dynamics. Nature 451, 279-283.

Zhang, Z., Wang, H., Guo, Z., Jiang, D., 2007. What triggers the transition of palaeoenvironmental patterns in China, the Tibetan Plateau uplift or the Paratethys Sea retreat? Palaeogeography, Palaeoclimatology, Palaeoecology 245, 317-331.

Zheng, J., He, X., Liu, S., 1999. Dictionary of Chinese stratigraphy-Tertiary. Geology Press, Beijing.

Zhong, S., 1992. Calcareous nannofossils from the Upper Cretaceous and lower Tertiary in the western Tarim Basin, south Xinjiang, China. Chinese Science Publishing House, Beijing.

Zhuang, G., Hourigan, J.K., Koch, P.L., Ritts, B.D., Kent-Corson, M.L., 2011. Isotopic constraints on intensified aridity in Central Asia around 12 Ma. Earth and Planetary Science Letters 312, 152-163. 


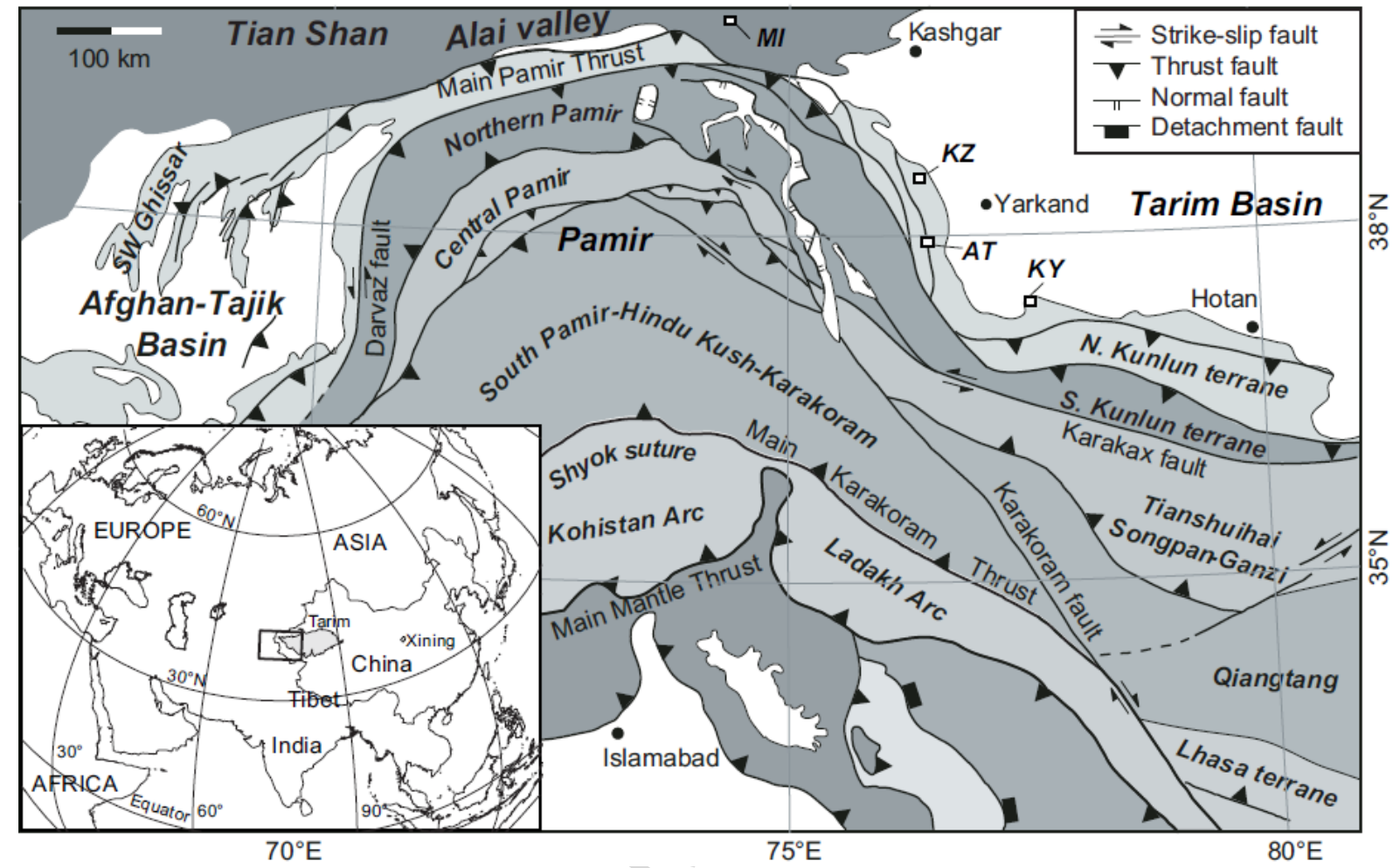

Figure 1 


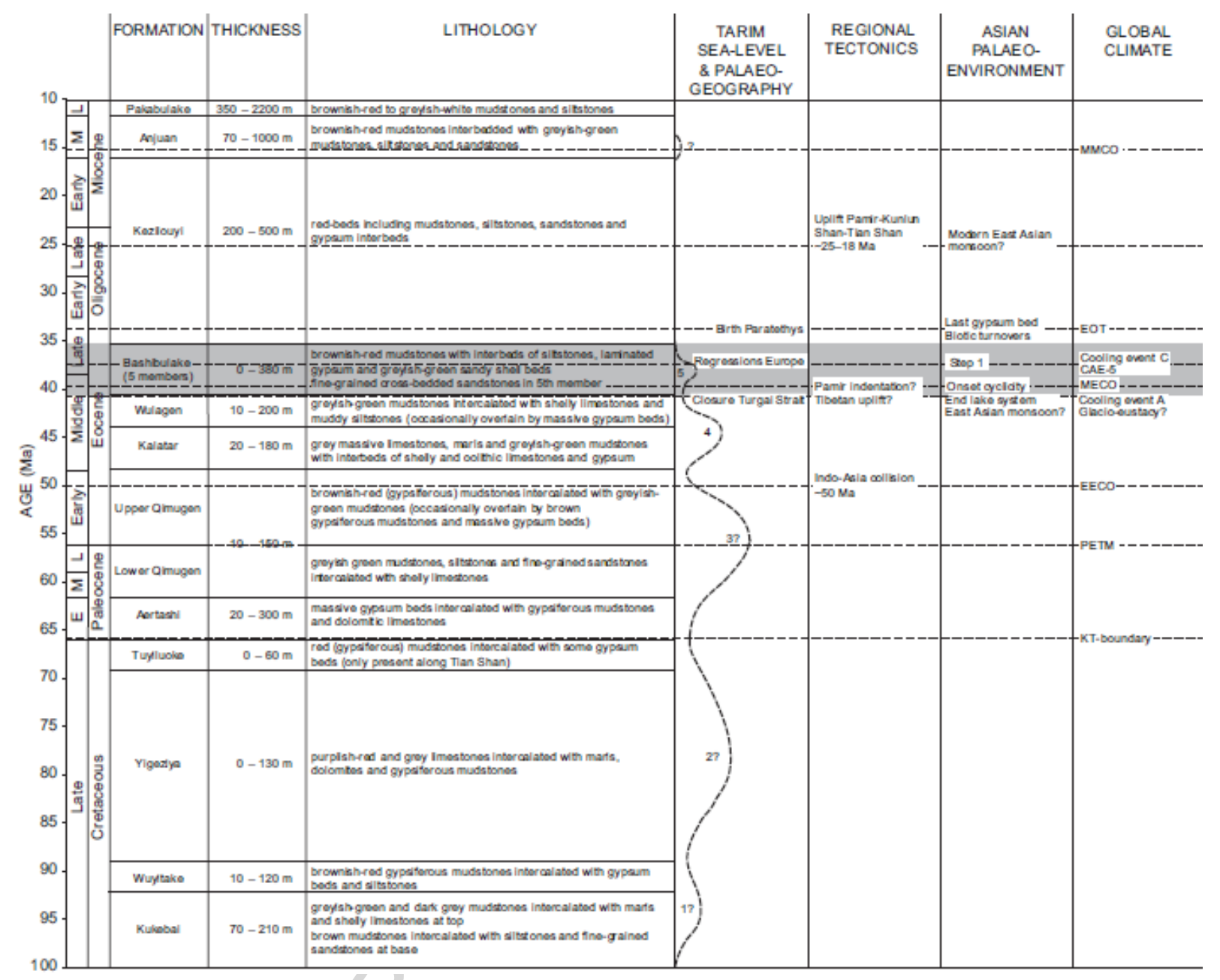

Figure 2 


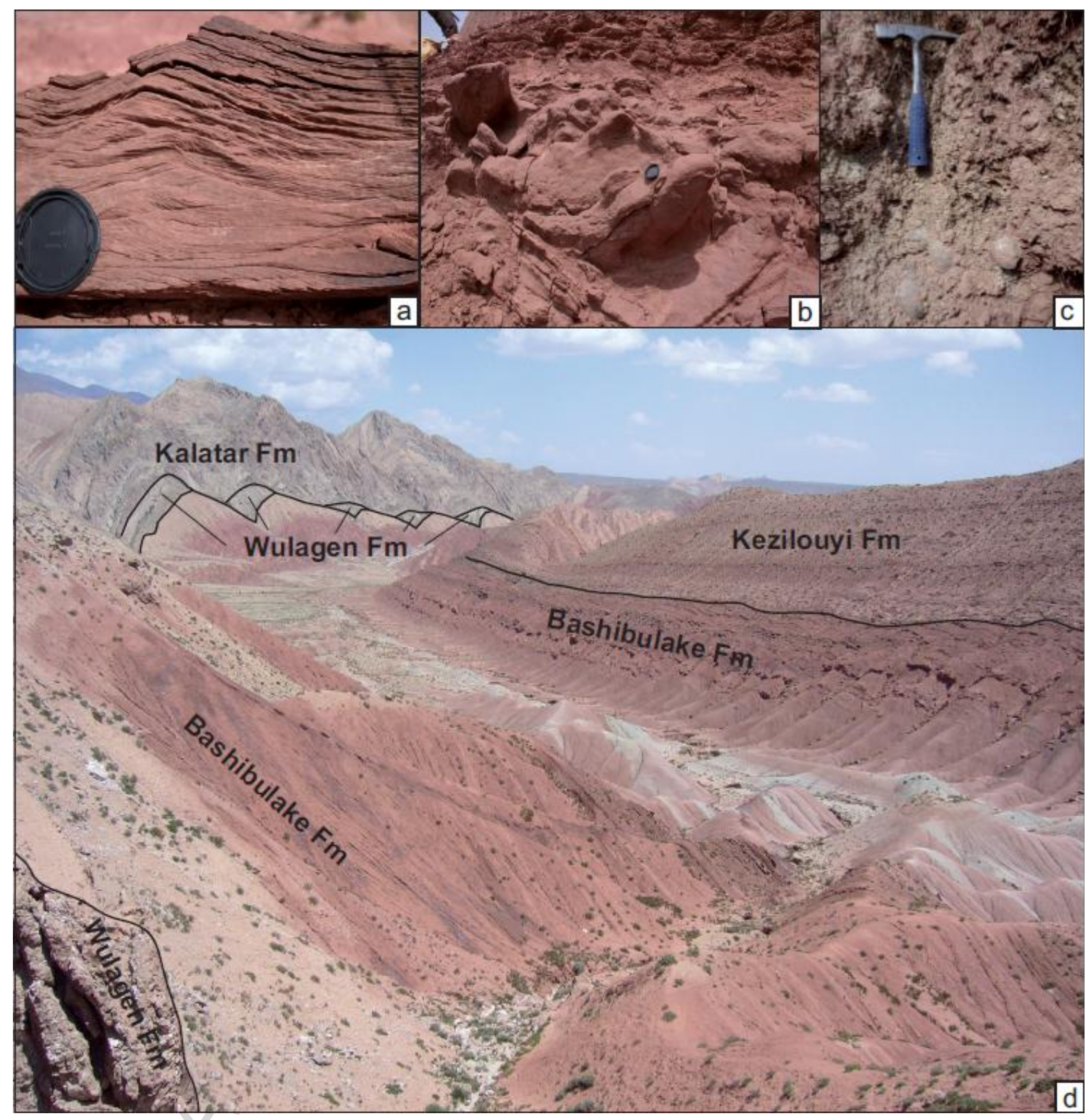

Figure 3 


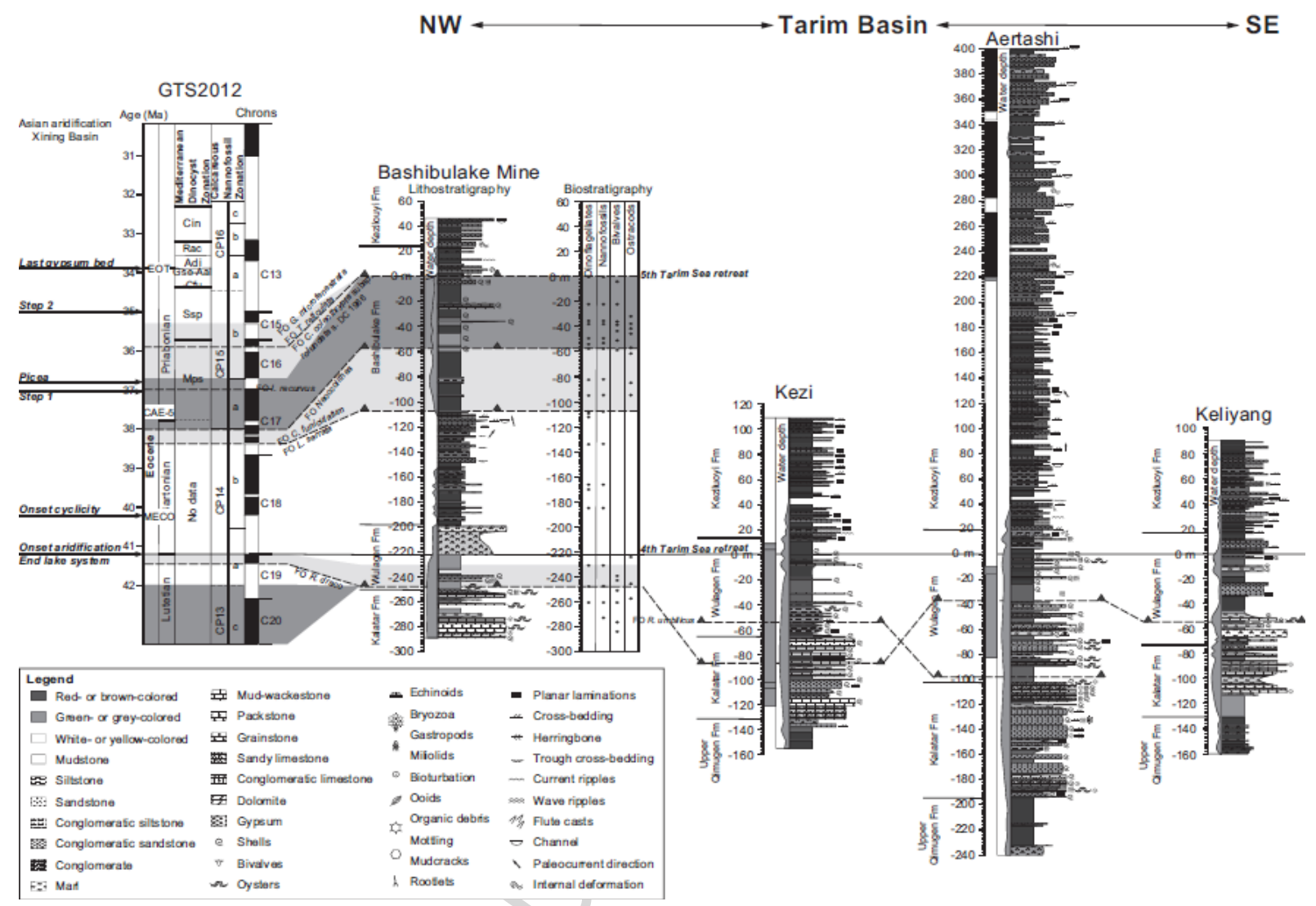

Figure 4 


\section{ACCEPTED MANUSCRIPT}

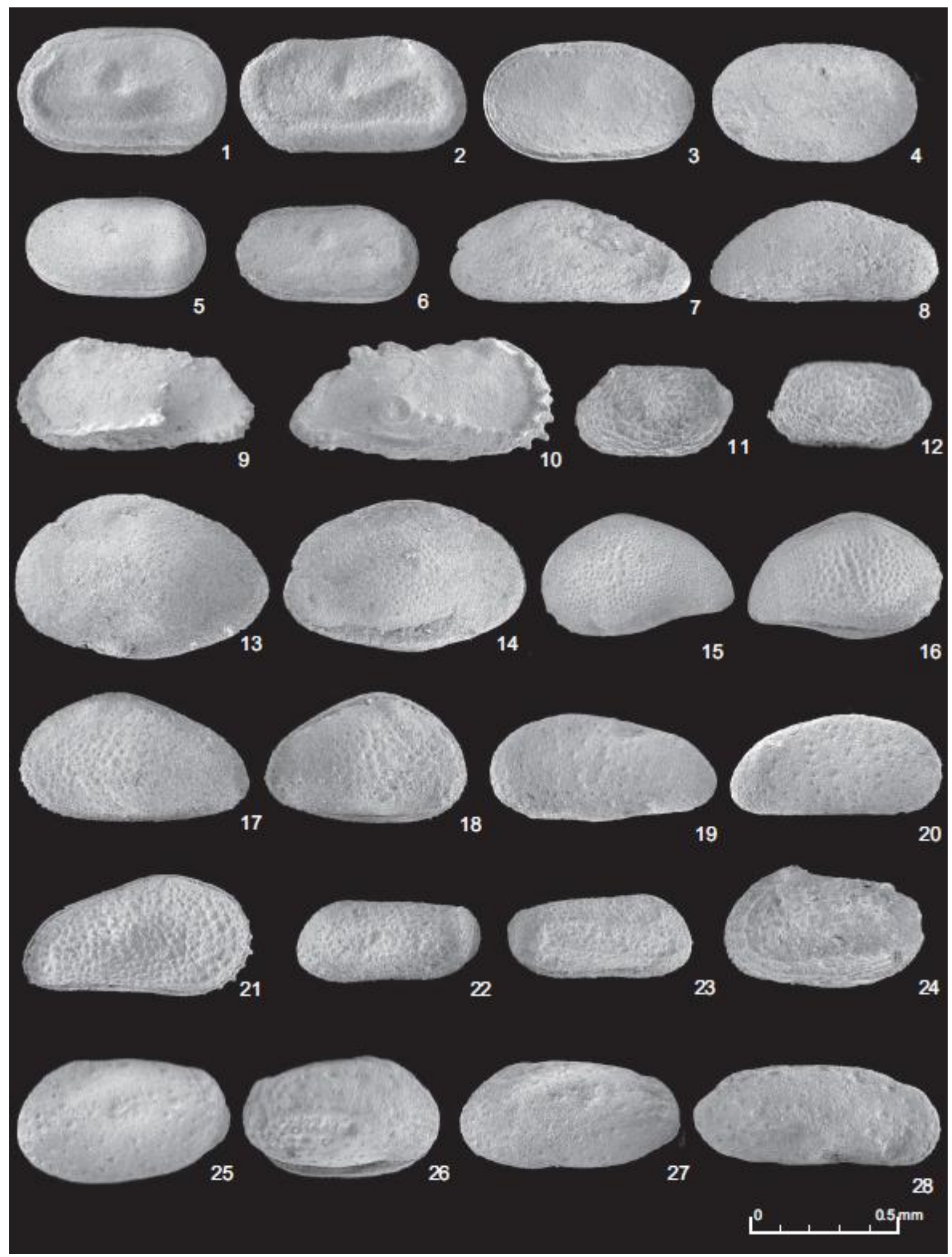

Figure 5a 


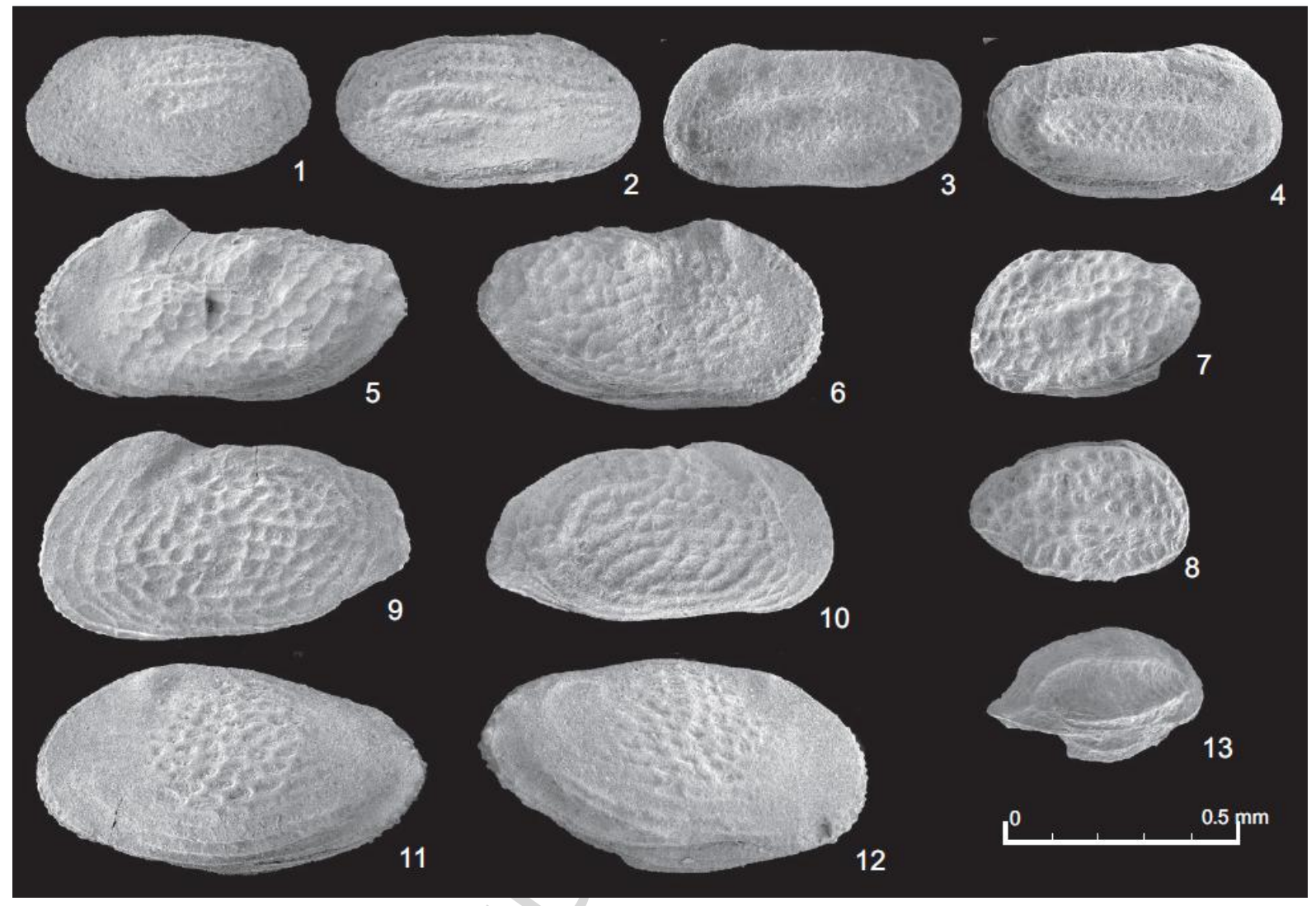

Figure 5b 


\section{ACCEPTED MANUSCRIPT}

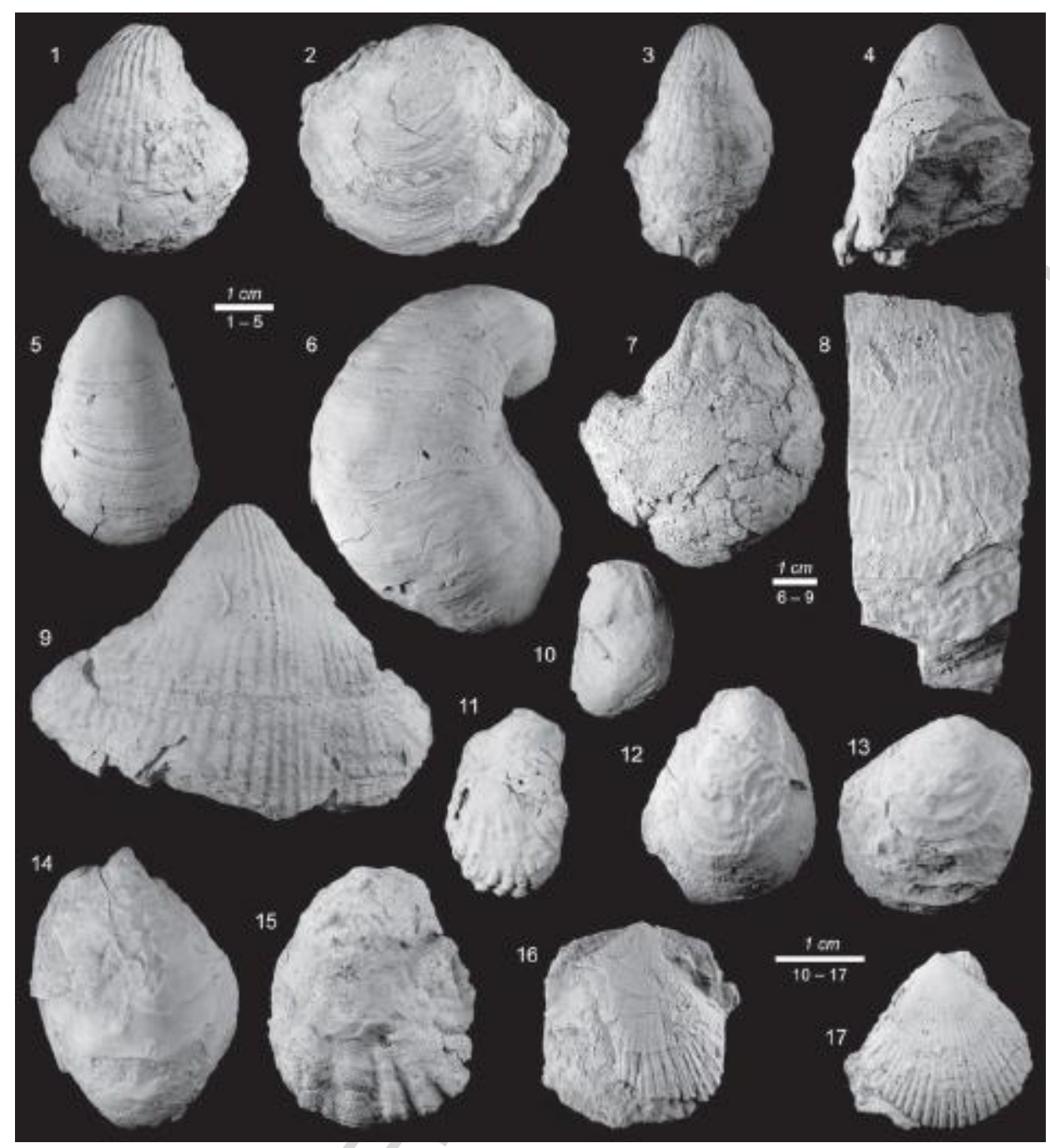

Figure 6 

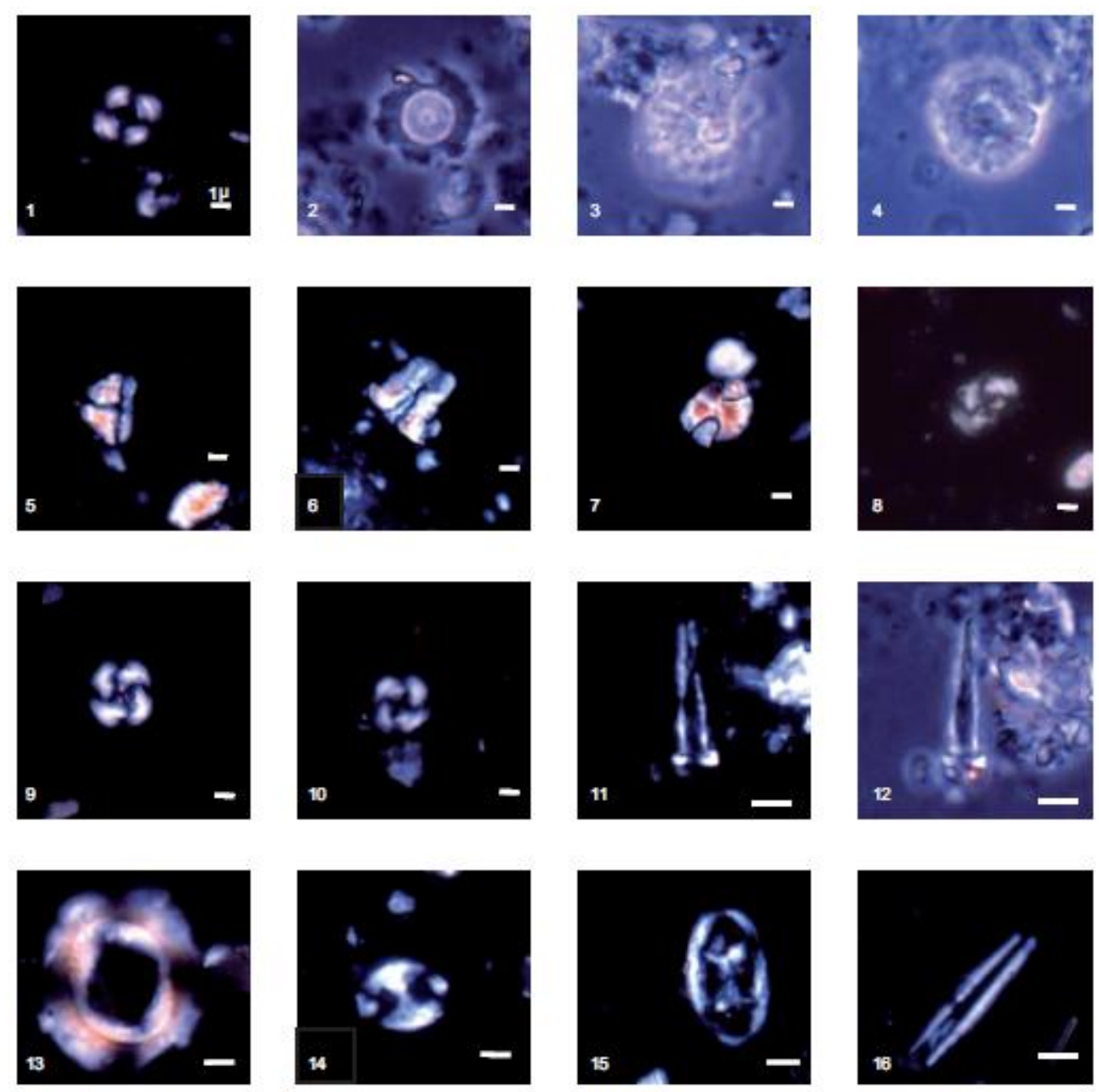

Figure 7 

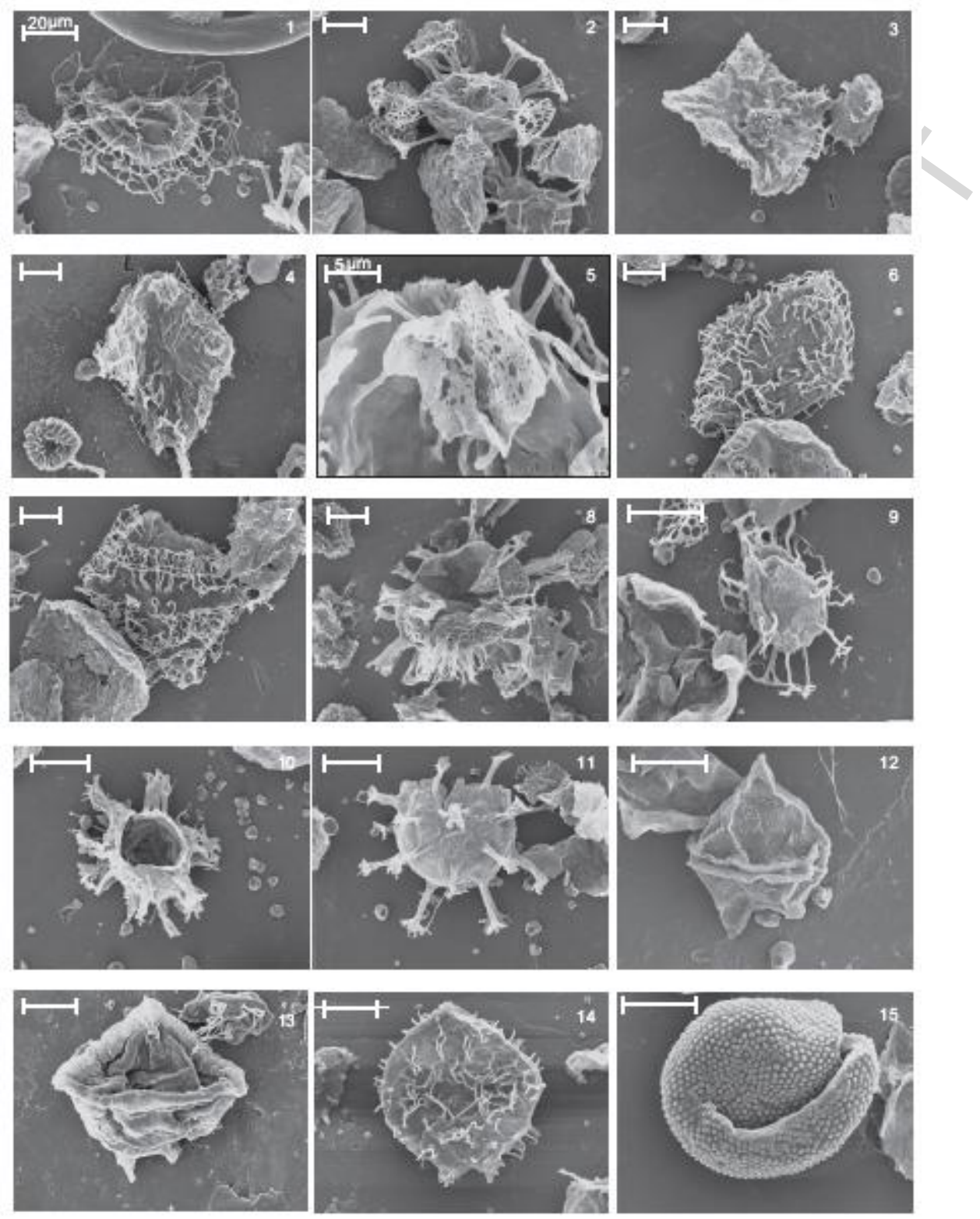

Figure 8 


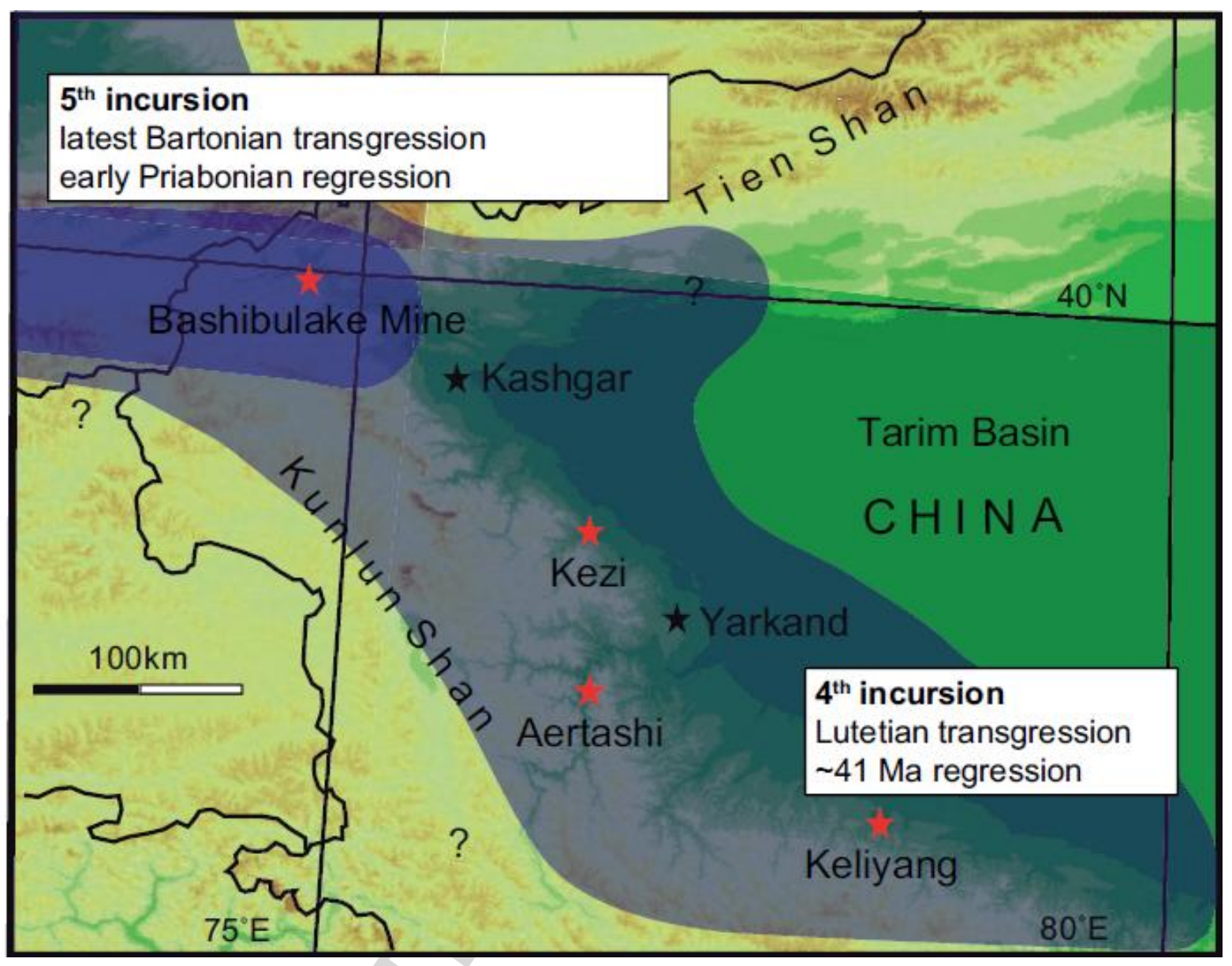

Figure 9 


\section{Timing, cause and impact of the late Eocene stepwise sea retreat from the Tarim Basin (west China)}

Roderic Bosboom, Guillaume Dupont-Nivet, Arjen Grothe, Henk Brinkhuis, Giuliana Villa, Oleg Mandic, Marius Stoica, Tanja Kouwenhoven, Wentao Huang, Wei Yang and ZhaoJie Guo

\section{Highlights}

- Fifth and last sea retreat step from Tarim Basin in early Priabonian.

- Shallow marine conditions and paleogeographic connection to Western Tethys maintained.

- Lack of diachroneity regressions suggests short-term eustatic forcing.

- Stepwise retreat over millions of years suggests long-term tectonic forcing.

- Stepwise retreat is concomitant with aridification steps Asian interior. 